\title{
Plectranthus barbatus: A Review of Phytochemistry, Ethnobotanical Uses and Pharmacology - Part 2
}

Authors

Affiliations
Rawiya H. Alasbahi ${ }^{1}$, Matthias F. Melzig ${ }^{2}$

${ }^{1}$ Faculty of Pharmacy, Department of Pharmacognosy, University of Aden, Crater-Aden, Yemen

${ }^{2}$ Institute of Pharmacy, Free University Berlin, Berlin, Germany
Key words

- Plectranthus barbatus

- Lamiaceae

- forskolin

- phytochemistry

- ethnobotanical uses

- pharmacology

- 6-(3-dimethylaminopropionyl)forskolin hydrochloride (NKH477) received May 19, 2009

revised Dec. 8, 2009

accepted January 25, 2010

\section{Bibliography}

DOI http://dx.doi.org/

10.1055/s-0029-1240919

Published online February 25, 2010

Planta Med 2010; 76: 753-765

(c) Georg Thieme Verlag KG

Stuttgart · New York.

ISSN 0032-0943

Correspondence

Prof. Dr. Matthias F. Melzig

Institute of Pharmacy

Free University Berlin

Königin-Luise-Str. $2+4$

14195 Berlin

Germany

Phone: + 493083851451

Fax: + 493083851461

melzig@zedat.fu-berlin.de

\section{Abstract}

$\nabla$

Plectranthus barbatus Andr. is one of the most important species of the genus Plectranthus L' Herit. (Lamiaceae), with a wide variety of traditional medicinal uses in Hindu and Ayurvedic traditional medicine as well as in the folk medicine of Brazil, tropical Africa and China. The plant has therefore been an attractive target for intensive chemical and pharmacological studies up to now. This review presents data about the phytochemistry, ethnobotanical uses and pharmacology of Plectranthus barbatus as well as the pharmacology of its constituents. In addition to essential oil, abietane diterpenoids and 8,13-epoxy-labd-14-en11-one diterpenoids are the main constituents found in Plectranthus barbatus. The major ethnobotanical uses are for intestinal disturbance and

\section{Pharmacology \\ $\nabla$ \\ Plectranthus barbatus}

Studies on several extracts with various polarities obtained from different parts of $P$. barbatus revealed a number of pharmacological properties that may justify most of the traditional uses of $P$. barbatus, for example, organic extracts were reported to possess anti-inflammatory, antimicrobial [1,2], antioxidant [3], cytotoxic [4], hypotensive [5,6], spasmolytic [7], hepatoprotective [8] and antifeedant [9] activities as well as activity against Ehrlich's ascites tumor in mice [10]. An alcoholic extract of the P. barbatus roots was shown to exhibit marked inhibitory action against Escherichia coli toxin-induced secretory response in rabbits and guinea pig ileal loops [11]. It has been shown that a hydroalcoholic extract of $P$. barbatus $(880 \mathrm{mg} / \mathrm{kg} /$ day) exerted a variety of toxic effects on the different periods of pregnancy in rats; for example, in the period before embryo implantation, it caused a delay in fetal development and liver fatigue, respiratory disorders, heart diseases and certain nervous system disorders. Forskolin as one of the major constituents with its unique adenylyl cyclase activation that underlies the wide range of pharmacological properties could explain the different traditional uses of Plectranthus barbatus. Forskolin is involved in a number of patented pharmaceutical preparations used as over-the-counter drugs for the treatment of several ailments. However, the water-insoluble nature of forskolin limits its clinical usefulness. Forskolin thus served as a prototype for the development of 6-(3-dimethylaminopropionyl)forskolin hydrochloride (NKH477) as a potent water-soluble forskolin derivative that finds use in the therapy for a number of diseases especially of the cardiovascular system. (WE) of the stems and leaves, at a dose of $1 \mathrm{~g} / \mathrm{kg}$ p.o., shortened the sleeping time induced by pentobarbital by $37 \%$, and at a dose of $2 \mathrm{~g} / \mathrm{kg} \mathrm{p}$.o. enhanced the intestinal transit of charcoal by $30 \%$ in mice. The WE $(2 \mathrm{~g} / \mathrm{kg} /$ intraduodenal $)$ also reduced the gastric secretions $(3.9 \pm 1.0$ to $0.5 \pm$ $0.2 \mathrm{~mL} / 4 \mathrm{~h})$, and total acid secretion $(34.4 \pm 11.0$ to $2.7 \pm 0.5 \mathrm{mEq} / \mathrm{L})$ and raised gastric $\mathrm{pH}(2.2 \pm 0.3$ to $6.5 \pm 0.8)$ in rats. The treatment with WE $(2 \mathrm{~g} /$ $\mathrm{kg}$ p.o.) was also found to protect against lesions induced by ethanol or cold-restraint stress, in pylorus-ligated rats [14]. Similar results were obtained by Schultz et al. [15] who reported that the WE of the leaves $(0.5-0.1 \mathrm{~g} / \mathrm{kg})$ injected into the duodenal lumen decreased the volume $(62$ and $76 \%$ ) and total acidity (23 and 50\%) of gastric 
acid secretion in pylorus-ligated mice. The water extract of $P$. barbatus leaves administered by gavage to young rats with and without cholestasis was reported to reduce weight gain, feed ingestion, and energy utilization in both groups in the same proportion. However, the water extract was found to inhibit, partially, the increase in liver wet weight, liver fat content and the serum levels of cholesterol and triacylgycerides caused by cholestasis [16]. Furthermore, $P$. barbatus extract fed to ovariectomized rats was found to reduce body weight, food intake and fat accumulation [17]. The essential oil extracted from the leaves of $P$. barbatus and one of its major components, i.e., $\alpha$-pinene, were reported to have a direct relaxant and spasmolytic effect on the guinea pig ileum [13].

A variety of pharmacological activities of $P$. barbatus were the subjects of a number of patents, for example, antispasmodic effects on smooth muscle of the respiratory system, antiasthmatic, cough-relieving and phlegm-expelling [18-20], inhibition of the absorption of alveolar bones [21], reduction of the total body weight [22,23], induction of lipolysis in rat adipose tissue [24] and inhibition of the $\alpha$-glucosidase [25] as well as promotion of subcutaneous fat decomposition [26]. Other patents presented an antiallergic effect [27], hair-loss preventing effect, and activation of the process of melanogenesis [28], an antiaging effect [29] as well as antimicrobial activity of the essential oil, with a certain composition (at least 7.5\% bornyl acetate, 3.5\% 3-decanone, $3.75 \%$ of an azulene derivative, $1 \% \alpha$-pinene, and $0.75 \% \beta$ pinene), extracted from $P$. barbatus root [30].

Adverse effects of Plectranthus barbatus: P. barbatus was reported to cause perianal dermatitis [31].

\section{Forskolin}

Forskolin (26) (see Fig. 2 in Part 1 of our Review [DOI: 10.1055/s0029-1240898]) is one of the most extensive studied constituents of $P$. barbatus. A great number of studies revealed the unique character of forskolin as a direct, rapid and reversible activator of adenylyl cyclase, which results in marked increases in the level of intracellular cyclic 3',5'-adenosine monophosphate (cAMP) in a variety of mammalian membranes, broken cell preparations and intact tissues [32-42]. Forskolin in the form of forskolin affinity columns has thus been used for the purification of the enzyme adenylyl cyclase $[43,44]$. Adenylyl cyclase exists in at least nine different membrane-associated isoforms and each isoform shows distinct patterns of tissue distribution and biochemical/pharmacological properties. Forskolin is a general activator of all but one of the adenylyl cyclase isoforms, namely, adenylyl cyclase 9 [45, 46]. Forskolin, for example, was found to differ from isoproterenol and prostaglandin E2 in the regulation of interleukin-10 (IL10 ) and tumor necrosis factor alpha (TNF- $\alpha$ ) in Kupffer cells, in which forskolin-insensitive adenylyl cyclase 9 mRNA is highly expressed and may be involved in the cAMP-mediated attenuation of TNF- $\alpha$ release. The strong cAMP activator forskolin was found to be no more potent than isoproterenol in reducing TNF- $\alpha$ levels and significantly reduces IL-10 levels [47].

The discovery of forskolin as a direct, rapid and reversible activator of adenylyl cyclase and its ability to manipulate the intracellular levels of cAMP precisely and to elicit cAMP-dependent physiological responses and later on the disclosure of its ability to exert a number of cAMP-independent effects have made forskolin a target for intensive pharmacological research up to the present.

\section{Pharmacological effects of forskolin}

cAMP-dependent effects: A number of studies on the various pharmacological effects of forskolin have been conducted mainly on laboratory animals but a few on humans. The fact that forskolin directly activates adenylyl cyclase and thus increases cAMP levels is considered as the mechanism of action that underlies the various pharmacological effects of forskolin. The following is a summary of the main pharmacological effects of forskolin mediated by the increase of the cAMP.

Cardiovascular effects: Forskolin was found to exert positive inotropic actions on the isolated guinea pig heart, isolated rabbit heart and on the dog and cat heart in situ. In addition, forskolin augmented coronary blood flow in the isolated guinea pig heart. It was reported that forskolin increased the heart rate and lowered the blood pressure in dogs, cats, rats and rabbits and also in spontaneously hypertensive and renal hypertensive rats. The cardiovascular effects of forskolin such as the inotropic effect could be explained primarily by the increase of cAMP in heart muscle, which is known to increase its contractility via opening of the slow $\mathrm{Ca}^{2+}$-channels, thus leading to elevation of intracellular calcium, and the hypotensive effect by the increase of cAMP in the vascular smooth muscle, which causes a relaxation due to the lowering of the calcium sensitivity of the contractile system of smooth muscle cells [5,48-50]. However, the inotropic and chronotropic effects of forskolin in conscious dogs were reported to be not only due to direct activation of adenylyl cyclase, but also mediated by neural mechanisms and potentiated by the prevailing level of sympathetic tone [51].

It has been demonstrated that forskolin exhibited concentrationdependent inhibitory effects on vascular contractility of rat aorta by decreasing the cytosolic $\mathrm{Ca}^{2+}$ level at a lower concentration $(0.1 \mu \mathrm{M})$ and decreasing the sensitivity of contractile elements to $\mathrm{Ca}^{2+}$ at a higher concentration $(1.0 \mu \mathrm{M})$ [52]. Repolarization and reduction in the intracellular $\mathrm{Ca}^{2+}$ sensitivity of force was found to be the primary mechanism of forskolin-induced relaxation of intact rat tail artery [53]. Forskolin as a vasodilator was reported to open the large-conductance calcium-activated potassium channels in coronary myocytes by cross-activation of protein kinase $C$. This signaling pathway represents a novel mechanism for regulation of potassium channel activity in various smooth muscle and other cells [54]. In addition, forskolin-induced relaxations of isolated rabbit aortic preparations, accompanied by increased cAMP were found to interact with endothelium-derived relaxing factor-dependent relaxations [55].

It has been shown that forskolin is a potent, powerful activator of myocardial adenylyl cyclase in human cardiac tissue preparations. It produced maximal effects that were 26-fold greater than basal activity in normal functioning and failing left ventricles, and 4.82- (normally functioning left ventricle) and 6.13- (failing left ventricle) fold greater than those of isoproterenol. Unlike isoproterenol, forskolin did not appear to approach a true maximum at higher concentration ranges, and stimulated cAMP production in a linear-log dose manner between $10^{-7}$ and $10^{-4} \mathrm{M}$. The adenylyl cyclase stimulatory effect of forskolin was synergistic with isoproterenol in preparations derived from a failing human heart. Forskolin was also found to produce a less potent positive inotropic effect $\left(\mathrm{ED}_{50} 3.5 \times 10^{-7} \mathrm{M}\right)$ than isoproterenol $\left(\mathrm{ED}_{50} 2.4 \times\right.$ $10^{-8} \mathrm{M}$ ) in isolated human right ventricular trabeculae and papillary muscles derived from severely failing human hearts [56]. In a clinical study, forskolin has been reported to improve coronary blood flow and myocardial function without increasing the myocardial oxygen consumption in 6 patients undergoing diagnostic 
catheterization of the heart [48]. Forskolin was also found to improve left ventricular function primarily via reduction of preload in 7 dilated cardiomyopathy patients without rising metabolic costs [57]. Moreover, in a comparative study of the cardiovascular effects of forskolin with dobutamine and sodium niroprusside in 12 patients with stage III (NYHA) congestive cardiomyopathy, forskolin was found to be able to induce a better cardiac performance than that produced by either dobutamine or by sodium niroprusside. On the other hand, a combination of both dobutamine and sodium nitroprusside was found to be able to produce a similar hemodynamic profile as forskolin [58]. Studies on the cardiodynamic profile of forskolin revealed a variation in the responsiveness of different cardiac tissues to forskolin, for example, coronary vasculature was found to be more sensitive to forskolin in comparison to pacemaker cells and ventricular muscle. This phenomenon could be explained by the existence of different subtypes of adenylyl cyclase with different affinities for forskolin [59]. Furthermore, forskolin was found to increase blood flow in the cerebrum, and increase flow to the myocardium and kidneys despite a decrease in mean arterial pressure. Forskolin did not alter cerebral oxygen consumption, which indicates that the increase in cerebral blood flow is a direct vasodilator effect [60].

Platelet aggregation inhibitory effect: Forskolin was reported to be a potent inhibitor of ADP-induced, arachidonate-induced and collagen-induced human, rat and rabbit platelet aggregation [5, 61]. Plasma adenosine was found to play an important role in the antiplatelet activity of forskolin [61]. Platelet aggregation induced by collagen, ADP, arachidonic acid, or epinephrine is inhibited by elevations in CAMP. An increase in the cAMP levels has been found to correlate with the degree of inhibition of ADP-induced aggregation [5] as well as with the progressive inhibition of fibrinogen binding in thrombin-stimulated human platelets [62]. In addition to its direct effects, a low concentration of forskolin was found to markedly augment the efficacy and potency of prostaglandins $[5,63]$ and aspirin [64] in inhibiting platelet aggregation. The anti-aggregating activity of forskolin was thus attributed to both direct stimulation of adenylyl cyclase and a marked enhancement of receptor-mediated stimulation of the enzyme [5].

Forskolin was found to exert an inhibitory effect in the excitatory signal transduction in the platelets at a site beyond phospholipase $C$ at the level of the $C$ kinase $[65,66]$. Since C-kinase activation is one of the key events in excitatory signal transduction in the platelets, it was suggested that the inhibitory effect of forskolin on platelet secretion and aggregation might reside in its capacity to antagonize C-kinase activity [65]. Other targets for the mechanism of the anti-aggregating activity of forskolin were found to be the increase in the nitric oxide synthase activity of human platelets by cAMP/cAMP-activated protein kinase [67] and the inhibition of platelet-activating factor binding to platelet receptors independently of adenylyl cyclase or G-protein involvement [68].

In a study using a subline of B16 murine melanoma, B16-F10 (highly metastatic to lungs), forskolin was reported to inhibit the melanoma cell-induced human platelet aggregation [69]. Moreover, the platelet anti-aggregating effect of forskolin was found to underlay the inhibitory effect of forskolin on hepatic metastasis from human colon cancer in nude mice during the metastatic tumor formation [70]. A $0.1 \%$ ethanolic solution of forskolin applied to the surface of polytetrafluoroethylene (PTFE) standard type grafts implanted into the superficial femoral arteries of ten healthy male Australian sheep was found to prevent platelet de- position (aggregation) on the surface of the PTFE grafts [71]. Moreover, addition of forskolin to platelet concentrates was found to inhibit the activation of platelets and therefore protect it from deleterious changes that may occur during storage [72].

Respiratory effects: It has been demonstrated that forskolin is able to relax airway smooth muscle in guinea pigs in vitro and in vivo [73-76] as well as in ovine isolated bronchioles [76]. In addition, forskolin was found to produce a partial reversal of tachyphylaxis to salbutamol- and isoprenaline-induced relaxation $[76,77]$. Forskolin has been shown to inhibit the immunologically stimulated release of LTD4 and histamine from sensitized guinea pig lungs [74]. The antiallergy effect of forskolin was identified by tests which measure the inhibition of anaphylactic bronchospasm in sensitized guinea pigs having antigen-induced bronchoconstriction. Forskolin was also found to inhibit allergen-induced histamine release from guinea pig and human sensitized tissue [78]. Inhalation of forskolin by asthmatics [79] as well as by healthy nonsmoker volunteers [80] was reported to improve respiration after provocation of bronchospasm with methacholine and acetylcholine, respectively. In a single-blinded clinical study in children and adult outpatients, forskolin capsules taken orally at $10 \mathrm{mg}$ a day were found to be more effective than sodium cromoglycate (two inhalations every $8 \mathrm{~h}$, three times a day) in preventing asthma attacks in patients with mild persistent or moderate persistent asthma [81]. Forskolin (as dry powder capsules) was found to produce bronchodilatation in 16 patients with asthma [82]. A number of studies, using animal models, demonstrated several mechanisms of forskolin to relax pulmonary smooth muscle such as the cAMP-dependent protein kinase (PKA) mediated inhibition of endothelin-1 stimulated generation of inositol phosphates and $\mathrm{Ca}^{2+}$ mobilization [83], the inhibition of the binding of inositol 1,4,5-triphosphate $\left(\mathrm{IP}_{3}\right)$ to its $\mathrm{Ca}^{2+}$-mobilizing intracellular receptor [84], the protein kinase $C$ isoenzymes mediated activation of large-conductance, calcium- and voltage-activated potassium channels and the resulting pulmonary vasodilatation [85], the decrease in the $\mathrm{Ca}^{2+}$ oscillation frequency of airway smooth muscle cells by reducing internal $\mathrm{Ca}^{2+}$ release through $\mathrm{IP}_{3}$ receptors [86], as well as the inhibition of myosin light chain (MLC) phosphorylation by reducing $\mathrm{Ca}^{2+}$ influx, $\mathrm{Ca}^{2+}$ release, by changing the MLC kinase/phosphatase balance and the inhibition of the MLC phosphorylation-independent regulatory mechanism [87]. It has also been reported that the relaxant effects of forskolin in cultured rat tracheal smooth muscle might be mediated, at least in part, by facilitating the sequestration of $\mathrm{Ca}^{2+}$ into intracellular stores by a mechanism involving guanosine 3',5'-cyclic monophosphate-dependent protein kinase [88]. Moreover, forskolin was shown to reverse airway hyperresponsiveness of bovine tracheal smooth muscle cells due to the inhibition of RhoA, a small G protein that plays an important role in the functional alterations of hyperresponsive tracheal smooth muscle cells [89].

Forskolin was found to reduce the expression of inflammatory mediators such as the surface adhesion molecules including ICAM- 1 and the release of granulocyte-macrophage colony-stimulating factor (GM-CSF) and interleukin-8 (IL-8) secreted by airway smooth muscle cells in diseases such as asthma [90]. It has been demonstrated that forskolin reduced airway smooth muscle cell mitogenesis and attenuated smooth muscle growth (that play a potential role in the generation of airway smooth muscle hyperplasia) by suppressing cyclin D1 expression [91] and through an EPAC (exchange protein directly activated by cAMP) or an EPAC-like cAMP-dependent mechanism [92]. Moreover, for- 
skolin was reported to increase the isometric contraction of the isolated hemidiaphragm in the presence of calcium [93].

Gastrointestinal tract: A number of studies reported that forskolin stimulated acid formation in rabbit and rat parietal cell preparations [94,95], in intact amphibian gastric mucosa [96], and both acid formation and pepsinogen secretion in isolated rabbit gastric glands [96,97], and, in vivo, rat gastric acid secretion [95]. Treatment of rabbit gastric glands and gland homogenates as well as dispersed rabbit parietal cells with forskolin resulted in an increase in cAMP levels [94-97], indicating the major role of cAMP in gastric secretion. As reported by Modlin et al. [98], the enhancement of phosphorylated bands around 92 kilodaltons by forskolin in isolated gastric glands illustrated the intracellular regulatory mechanisms of gastric secretion. Moreover, forskolin, at $1 \mathrm{mg} / \mathrm{loop}$, was found to be able to exhibit almost similar anti-secretory (antidiarrheal) activity as loperamide (anti-secretory opiate agonist) $1 \mathrm{mg} / \mathrm{loop}$, against Escherichia coli enterotoxins-induced secretory response in animal ileal loop models [11]. Intra-arterial injection of forskolin $(3-100 \mu \mathrm{g})$ in blood-perfused dog pancreas was reported to cause a dose-dependent increase in the secretion of pancreatic juice mediated through an increase of intracellular cAMP concentration [99]. Forskolin was shown to relax smooth muscles of cat intestine, rat intestine and uterus as well as rabbit duodenum and guinea pig ileum $[5,100]$. A combination of forskolin and saponin was reported to improve bowel movement without side effects such as abdominal pain and habit formation [101].

Genitourinary tract system: It has been demonstrated that forskolin caused a concentration-dependent relaxation of rabbit and porcine detrusor muscle [102,103], as well as a stimulation of rennin release from isolated perfused rat kidney [104]. As reported by Bishop and coauthors [105], forskolin, injected directly into the bladder or administered intravenously to type 1 fimbriated uropathogenic Escherichia coli infected mice, induced exocytosis of bladder epithelial cells fusiform vesicles in which $E$. coli is incorporated and thus reduced the number of intracellular E. coli and exposed the bacteria to the antibiotics. The inhibitory effect of forskolin on the contractions of the uterine rings from rats at 16 days of gestation was found to involve the activation of adenylyl cyclase, the adenosine triphosphate-dependent potassium channels and, to a greater extent, calcium-dependent potassium channels [106]. Moreover, intrarenal infusion of forskolin in anesthetized dogs was reported to cause natriuresis with increasing renal blood flow and glomerular filtration rate, which is due to the ability of forskolin to preferentially dilate the afferent arterioles [107].

Eye: Topical ocular administration of $1 \%$ forskolin suspension in rabbits, monkeys and human volunteers, who were free from eye disease, was reported to lower the intraocular pressure as a result of a reduction of the net aqueous flow without significant change in outflow facility [108-112]. Nevertheless, lowering the intraocular pressure in rabbits by forskolin was also ascribed to increasing outflow facility [113]. Prevention of myosin light chain phosphorylation by forskolin and consequent relaxation of actin cytoskeleton in bovine trabecular meshwork cells was considered as the mechanism that underlies the increased outflow facility in response to forskolin [114].

As reported by Caprioli et al. [109, 111], forskolin (1\% suspension) acted as a direct potent stimulator of adenylyl cyclase in both rabbit and human ciliary processes, as well as in human cultured ciliary epithelial cells, and increased the iris-ciliary blood flow (2.5-fold in rabbits) which is explained by a direct vasodilatory effect in the ciliary body. The authors also recorded no changes in blood pressure and pulse during and after topical ocular delivery of forskolin in rabbits and humans, and observed no tolerance to the intraocular pressure lowering effect in rabbits after topical doses given every $6 \mathrm{~h}$ for 15 days. In addition, forskolin was found to stimulate cAMP production in rabbit cultured corneal epithelial cells, increase cAMP concentration in the aqueous humor 10fold and cause a prolonged reduction of intraocular pressure and a decrease in aqueous humor formation [115]. It has however been shown that topical application of $1 \%$ forskolin did not significantly decrease the intraocular pressure in glaucomatous monkey eyes after the second day of the treatment [116]. Moreover, a study on the ocular penetration of $1 \%$ forskolin suspension, using albino rabbits, revealed a poor ocular penetration of forskolin (only $0.03 \%$ of the instilled forskolin penetrated the ocular tissue of the rabbit) which is considered to be the cause for the weak intraocular pressure lowering effect of forskolin [117].

Skin: It has been reported that forskolin after a relatively long lag period, induced the production of melatonin in cultured Syrian hamster pineal glands [118]. Forskolin was found to cause a significant increase in human hair follicle melanogenic activity and consequently a significant increase in pigmented hair follicles [119], and to stimulate the growth of hair follicular keratinocytes and melanogenesis in vitro $[120,121]$. In addition, it has been demonstrated that compositions containing solubilized $2 \% \mathrm{w} / \mathrm{w}$ of forskolin and $5 \%$ freeze-dried liquid endosperm of Cocos nucifera or $1 \%$ forskolin and 1\% 9,10-dimethoxy-2-mesitylimino-3methyl-2,3,6,7-tetrahydo-4H-pyrimido[6,1-a]isoquinolin-4-one hydrochloride were able to promote hair growth in animal models [122,123]. Moreover, forskolin was found to protect keratinocytes from UVB-induced apoptosis and increase DNA repair independent of its effects on melanogenesis. Although the induction of new pigment synthesis requires several days, the action of forskolin on DNA repair appears to be efficient when applied only a few minutes before UVB exposure [124,125]. A composition based on labdane diterpenoids including forskolin was found to provide better photoprotection against both UV A and UV B radiation in the HaCaT human keratinocyte cell lines and to enhance melanogenesis in B16F1 mouse melanoma cells and to act as a tanning inducer/accelerator both in the presence or absence of sunlight [126]. It has been demonstrated that topical application of a cream containing forskolin to the skin of patients with hyperplastic disease for 5 days caused healing to slight erythema or full recession [127]. Moreover, forskolin was reported to improve symptoms in 4 patients with psoriasis [48].

Tumor: Forskolin was found able to inhibit pulmonary tumor colonization and metastasis in mice. A single dose of forskolin ( $82 \mu \mathrm{g} /$ mouse) administered intraperitoneally 30 or 60 minutes prior to tail vein injection of cultured B16-F10 cells ( 2 or $3 \times 10^{5}$ cells/mouse) reduced tumor colonization in the lungs by more than 70\% [69]. Forskolin also inhibited the growth of the human gastric adenocarcinoma cell line AGS with a half-maximal inhibition achieved at $20 \mu \mathrm{M}$ [128]; also it prevented the growth and induced apoptosis of myeloid and lymphoid cells [129]. In studies using human gastric cancer cell lines BGC-823 and SGC-7901, forskolin was reported to inhibit cell growth by decreasing the activity of protein kinase $\mathrm{C}(\mathrm{PKC})$ and inhibiting the gene expression of PKC subunits (PKC $\beta$ and $\gamma$ ) and of some oncogene proteins such as Ha-ras and c-jun $[130,131]$ and by down-expression of the rasp21 protein and p53 protein [132], respectively. In addition, forskolin has been demonstrated to partially inhibit cytokinedriven colony formation and proliferation of $\mathrm{CD} 34^{+}$bone marrow 
cells $\left(\mathrm{NBM}^{\mathrm{CD} 34+}\right)$ without inducing either apoptosis or protein phosphatase 2A (PP2A) activity. Thus, the effects of forskolin on NBM cells most likely depend on its ability to activate adenylyl cyclase and induce cAMP, which inhibits cytokine-dependent proliferation of normal myeloid progenitors [133]. Addition of rolipram $(10 \mu \mathrm{mol} / \mathrm{L})$, known to maximally inhibit cyclic nucleotide phosphodiesterase type 4 , to a low dose of forskolin $(1 \mu \mathrm{mol} / \mathrm{L})$ enhanced the growth suppression induced by forskolin and caused complete growth cessation of chemoresistant KM12C colon cancer cells, despite rolipram having no effect on its own [134]. A composition containing adenylyl cyclase activators such as forskolin, theophylline, and isobutylmethylxanthine with carboxyamidotriazole was found to display synergistic antitumor effects and to inhibit the proliferation of tumor cells [135].

Contradictory to the above studies, a combination of forskolin and theophyllin (as cAMP increasing agents) was reported to attenuate the execution of the apoptotic process generated by etoposide, camptothecin, heat shock, cadmium chloride and X-radiation in promonocytic leukemia cells. This anti-apoptotic action is explained by the ability of the forskolin/theophylline combination to inhibit retinoblastoma (type 1) phosphatase and ICE/ CED-3-like protease activities, and the abrogation of c-myc expression in myeloid cells [136]. Moreover, other studies indicated that forskolin prevented the generation of apoptosis in human leukemia U937 cells [137] and stimulated cell growth, increased cAMP in the cells and enhanced the metastasis-related phenotypes including adhesion to laminin (Ln) and human umbilical vein epithelial cells (HUVEC), chemotactic migration and invasion in the H7721 human hepatocarcinoma cell line [138].

Weight management: The lipolytic activity of forskolin was reported to be mediated by the cAMP activity $[40,139]$. However, it has been demonstrated that forskolin-induced lipolysis in intact rat fat cells and the cell-free system consisting of intact lipid droplets and the lipase was not correlated with cyclic AMP content [140]. Some other studies also indicated the inconsistencies observed when the intracellular cAMP levels are correlated with lipolysis. They demonstrated that the cAMP concentration required to reach maximum lipolysis was higher for forskolin than for isoproterenol in digitonin-permeabilized adipocytes [141] and in intact adipocytes [142], as well as in isolated rat fat cells $[143,144]$. A similar observation was made by Schimmel [145] in hamster white adipocytes, who also reported that isoproterenol potentiation of forskolin's lipolytic action was not accompanied by increasing the cAMP content and persisted in the absence of extracellular $\mathrm{K}^{+}$, even though the lipolytic response to isoproterenol alone was absent in $\mathrm{K}^{+}$-free media. It has been shown that forskolin induced lipolysis in rat fat cells by stimulating the translocation of hormone-sensitive lipase from the cytosol to its substrate on the surface of the lipid droplets in fat cells [146]. It is postulated that the lipolytic responses of adipose tissue are more complex and other cyclic AMP-independent lipolytic mechanisms may be involved in the regulation of lipolysis in adipocytes [140,144,145].

In an animal model of obesity, forskolin - given by means of gastric intubation at $2 \mathrm{mg} / \mathrm{mice} /$ day in a divided dose - was found to reduce the body weight and fat significantly [147]. Some studies $[148,149]$ reported that topical application of forskolin cream reduced the local fat from the thigh of obese women without diet or exercise.

\section{Miscellaneous pharmacological activities}

Forskolin was found to be able to inhibit interleukin-2 (IL-2)-secreting T helper 1 lymphocytes in vitro and decrease IL-2 production and IL-2R $\alpha$ (IL-2 receptor $\alpha$-chain) expression and thus be able to suppress immunological responses to alloantigens and prevent acute allograft rejection. The increase in cAMP induced by forskolin is also considered to have an inhibitory effect on the generation of cytotoxic T lymphocytes, which are considered to play a role in the course of acute allograft rejection [150]. However, in various in vitro and in vivo test methods, forskolin was found to be able to increase the immunological activity of the recipient (mice) by stimulating the antibody response, increasing the cellular immune response (DTH response), and the macrophage activity [151]. Forskolin has been shown to protect the mouse neuronal cell line, Neuro 2A, against diisopropyl fluorophosphate, a surrogate of the organophosphate chemical warfare agents soman and sarin induced toxicity. This protective effect was found to be due to the ability of forskolin to activate the acetylcholinesterase promoter and upregulate its expression [152]. In an animal model using rats, repeated oral administration of forskolin $(50 \mathrm{mg} / \mathrm{kg})$ was reported to reduce the alcohol consumption significantly [153]. Moreover, forskolin was found to protect cultured cerebellar granule neurons (from wild-type mice) against alcohol-induced cell death by promoting the expression of neuronal nitric oxide synthase and increasing its activity [154]. It has also been demonstrated that forskolin showed anti-passive cutaneous anaphylaxis and mast cell stabilizing activity [155] and caused an inhibition of IgE-mediated release of histamine and peptide leukotrienes C4 from human basophils and lung mast cells [156]. Testing forskolin for anti-inflammatory activity using procedures such as the acute carrageenin-induced rat paw edema test, croton oil-induced rat ear inflammation test, and adjuvant-induced arthritis test in rats revealed that forskolin displayed an anti-inflammatory effect with $\mathrm{ED}_{50}: 4.80 \mathrm{mg} / \mathrm{kg} /$ i. $p$., $\mathrm{ED}_{50}: 1.15 \mathrm{mg} / \mathrm{ear}$ and $\mathrm{ED}_{50}: 2.5-2.4 \mathrm{mg} / \mathrm{kg} /$ i.p. (ca. $23-27 \%$ inhibition of developing and established arthritis) respectively, [157, 158].

As reported by Maeda et al. [159], forskolin $(0.01 \mathrm{mg} / \mathrm{kg})$ displayed a potential antidepressant effect, stronger (150 times) than that produced by amitriptyline $(15 \mathrm{mg} / \mathrm{kg})$ in the forced swimming test. At a high dose $(1.0 \mathrm{mg} / \mathrm{kg})$ of forskolin, the duration of immobility was returned to control level. Subcutaneous injection $(1 \mathrm{mg} / \mathrm{kg})$ and intracerebroventricular administration (10 and $100 \mu \mathrm{g}$ ) of forskolin into mice was found to prevent seizures induced by pentylenetetrazole [160] and depress spontaneous locomotor activity [161], respectively. A preliminary study demonstrated that intravenous infusion of forskolin (75 minutes) to four depressed and five schizophrenic patients caused a transient mood elevation in all four depressed patients and in two of the five schizophrenic patients [162]. It has been reported that forskolin reversed the inhibitory effect of amyloid beta-peptide on the protein kinase A/activated cAMP response element binding protein (PKA/CREB) pathway in cultured hippocampal neurons and consequently promoted the recovery of long-term potentiation formation. Forskolin therefore has been found able to reverse some of the risks related to higher amyloid beta levels that play a crucial role in Alzheimer's disease [163]. It was found that forskolin enhanced the function of fibroblast growth factor 8 on dopaminergic differentiation from human fetal mesencephalic neural progenitor cells and thus increased the production of dopaminergic neurons, which can be used in the therapy for neurodegenerative diseases [164]. 
Forskolin was reported to stimulate the release of insulin and glucagon from the pancreatic islets both in vitro and in vivo. Stimulating the release of insulin by forskolin required the presence of a stimulatory glucose concentration of about $5.6 \mathrm{mM}[165,166]$. Furthermore, it has been demonstrated that feeding forskolin to normal rats caused an increase in blood glucose, serum insulin, glucagon and free fatty acid levels with a corresponding increase in glucose-6-phosphatase activity and depletion of liver glycogen. This effect is due to the predominant stimulation of pancreatic $\alpha$-cells and the cAMP formation. The increase in blood glucose level and glucagon amount in forskolin-fed alloxan diabetic rats compared to untreated alloxan diabetic controls was explained by the stimulatory effect of forskolin on glucagon and the release and/or increase formation of cAMP [165]. In addition, forskolin was found to augment the insulinotropic action of gliquidone (a hypoglycemic sulfonylurea) in the perfused pancreas of normal and Goto-Kakizaki rats at a low concentration of glucose $(2.8 \mathrm{mM})$ as well as to disclose the glucagonotropic potential of gliquidone that was otherwise not detected in diabetic animals [167].

In a clinical investigation in 31 patients with vasculogenic impotence resistant to standard 3-agent pharmacotherapy, an overall $61 \%$ improvement in rigidity and/or erection duration without adverse events, was reported by using intracavernosal forskolin $(98 \mu \mathrm{g} / \mathrm{mL})$ in combination with papaverine $(29 \mathrm{mg} / \mathrm{mL})$, phentolamine $(0.98 \mathrm{mg} / \mathrm{mL})$ and prostaglandin E1 $(9.8 \mu \mathrm{g} / \mathrm{mL})$ [168]. Forskolin was also reported to increase the progressive motility and the percentage of motile cells of human sperm in vitro in a dosedependent manner $[169,170]$. It has been shown that forskolin, using dog thyroid slices, potentiated as well as mimicked the effect of thyrotropin-releasing hormone (THS) on iodide organification and secretion [171].

\section{cAMP-independent effects of forskolin}

In addition to cAMP-dependent effects, forskolin exerts a number of cAMP-independent effects through a mechanism that does not involve the production of cAMP [172] such as the inhibition of a number of membrane transport proteins, for example, the inhibition of glucose transporter in rat and human adipocytes [173, 174], human erythrocytes [175], human platelets [176], and bacterial galactose- $\mathrm{H}^{+}$transport protein GaIP [177] as well as the modulation of ion channels such as voltage-dependent $\mathrm{K}^{+}[178$, $179], \mathrm{Na}^{+}[180]$ and $\mathrm{Ca}^{2+}$ channels $[181,182]$, and inhibition of nicotinic acetylcholine receptor currents $[183,184]$ and the 5-hydroxytryptamine receptor mediated current $[185,186]$. Further examples of cAMP-independent effects of forskolin are the partial reversal of doxorubicin resistance in multidrug resistance (MDR) lines in a dose-dependent fashion by enhancing the accumulation of doxorubicin in resistant cells [187], the increase of the adriamycin cytotoxicity in human ovarian carcinoma cells by inhibiting the P-glycoprotein multidrug transporter [188], the partial protection of $L 929$ cells against tumor necrosis factor-alpha mediated cytotoxicity (internucleosomal DNA fragmentation) [189], and the activation of cytochrome P450 3A1 and 3A4 (CYP3A1 and CYP3A4) gene expression [190,191].

Forskolin was found to accelerate the desensitization of $\mathrm{GABA}_{\mathrm{A}}$ and glycine receptors by a cAMP independent mechanism presumably by acting directly on extracellular sites of the receptors [192]. It has been demonstrated that forskolin modulated the desensitization of the nicotinic acetylcholine receptor by both cAMP-dependent $[193,194]$ and cAMP-independent mechanisms when used at concentrations above $20 \mu \mathrm{M}[195,196]$.
Studies of the bone anti-resorptive property of forskolin on rat osteoclasts showed that forskolin exerted a bimodal cAMP-independent effect on superoxide anion $\left(\mathrm{O}^{2-}\right)$ generation by bone-resorbing rat osteoclasts, being stimulatory at a low dose (1 mM) and having an inhibitory effect at a higher dose (10 mM) [197] although the dual effect of forskolin in earlier studies was believed to be due to the elevation of cAMP [198]. The inhibition of platelet-activating factor binding to platelet receptors by forskolin was found to be independent of adenylyl cyclase or G-protein involvement [68].

Recently, it has been found that forskolin is a potent protein phosphatase 2A (PP2A) activator, it induced marked apoptosis, reduced proliferation, impaired colony formation, inhibited tumorigenesis and restored differentiation of BCR/ABL-transformed cells regardless of their degree of sensitivity to imatinib. The antileukemic effects of forskolin appear to depend on the induction of PP2A activity rather than an increased intracellular cAMP and/or PKA activation, as exposure of BCR/ABL-transformed cells to the cAMP inducer theophylline or to a PKA inhibitor did not alter BCR/ABL expression/activity [133].

\section{Adverse effects of forskolin}

Large doses of forskolin were found to cause a depressant action on the central nervous system in mice [100]. Due to the ability of forskolin to induce CYP3A gene expression in primary hepatocytes by functioning as pregnane $\mathrm{X}$ receptor ligands and thus be more likely to interfere with the metabolism of other drugs, Ding and Staudinger [199] suggested that herbal therapy with P. barbatus extract should be approached cautiously in patients on combination therapy. Moreover, Putnam et al. [200] recommended that patients with autosomal dominant or recessive polycystic kidney disease (PKD) should avoid using forskolin in any form because a forskolin-like substance has been identified within the cyst fluid of 15 patients out of 18 patients with PKD.

\section{Pharmacological effects of forskolin analogues and other natural occurring constituents of Plectranthus barbatus}

Isoforskolin (35) (see Fig. 2 in part 1) was reported to stimulate cAMP mildly $[49,201]$ and thus decrease blood pressure and produce an inotropic effect less than that of forskolin $[49,202,203]$. Isoforskolin was found to be able to relax guinea pig tracheal spirals [204], and at $1 \mathrm{mg} / \mathrm{loop}$ to exhibit a comparable antisecretory (antidiarrheal) activity as loperamide ( $1 \mathrm{mg} / \mathrm{loop}$ ) against $E$. coli toxin-induced secretory response in animal ileal loop models [11]. A composition based on labdane diterpenoids including isoforskolin was reported to protect HaCaT human keratinocyte cell lines against both UV A and UV B radiation, enhance melanogenesis in B16F1 mouse melanoma cells and act as a tanning inducer/ accelerator both in the presence or absence of sunlight [126]. Isoforskolin - given by means of gastric intubation at $2 \mathrm{mg} / \mathrm{mice} /$ day in a divided dose - was found to reduce the body weight and fat significantly [147].

1-Acetylforskolin (34) (see Fig. 2 in part 1) was found to stimulate the adenylyl cyclase slightly and to suppress rabbit ocular hypertension [201].

7-Deacetylforskolin (37) (see Fig. 2 in part 1) was shown to display a blood pressure lowering effect less potent than that of forskolin in anesthetized cats [5,49,202], but equipotent with forskolin in spontaneously hypertensive rats [5]. 7-Deacetylforskolin (1\%) was found to suppress rabbit ocular hypertension [201]. It has been reported that 7-deacetylforskolin was able to activate 
adenylyl cyclase mildly $[49,201,205]$, and to exert a cAMP-independent inhibition of glucose transport and cytochalasin B binding in rat adipocyte plasma membranes [205]. In an animal model, 7-deacetylforskolin was found to reduce the body weight and fat significantly [147].

9-Deoxyforskolin (27) (see Fig. 2 in part 1) was found to retain some activity on cyclic AMP generating systems but was inactive in lowering blood pressure even at a high dose $(1 \mathrm{mg} / \mathrm{kg})$ in anesthetized cats [49].

1,9-Dideoxyforskolin (28) (see Fig. 2 in part 1) was reported to lack an adenylyl cyclase activating function and therefore does not exhibit any of effects mediated by cAMP $[37,49]$. On the other hand, the inhibition of contractions of uterine rings from rats at 16 days of gestation by 1,9-dideoxyforskolin was attributed to an activation of adenylyl cyclase and calcium-dependent potassium channels [106]. Testing the anti-inflammatory effect of 1,9dideoxyforskolin - using procedures such as carrageenin-induced rat paw edema test, croton oil-induced rat ear inflammation test and adjuvant-induced arthritis test in rats - indicated that 1,9-dideoxyforskolin displayed an anti-inflammatory effect with $\mathrm{ED}_{50}$ values of $2.2 \mathrm{mg} / \mathrm{kg} /$ i.p., $1.6 \mathrm{mg} /$ ear, and $3.0 \mathrm{mg} / \mathrm{kg} /$ i.p., respectively. 1,9-Dideoxyforskolin was also found to exert an analgesic effect with an $\mathrm{ED}_{50}$ of $9.0 \mathrm{mg} / \mathrm{kg} /$ s.c. by using the acetic acid induced writhing test in mice $[157,158]$.

It has been demonstrated that 1,9-dideoxyforskolin is able to produce many cAMP-independent effects such as inhibition of glucose transport and cytochalasin B binding in rat adipocyte plasma membranes [205], augmentation of late voltage-dependent $\mathrm{Na}^{+}$channel activity in cardiac ventricular myocytes [180], inhibition of the basal cardiac L-type $\mathrm{Ca}^{2+}$ current [181] as well as inhibition of $\mathrm{Ca}^{2+}$ influx induced by $\mathrm{K}^{+}$in the rat pheochromocytoma cell line (PC12) [182], and in rat cerebellar granule cells [206] and by $\mathrm{K}^{+}$or nicotine in chromaffin cells [183]. 1,9-Dideoxyforskolin was found to inhibit the nicotinic acetylcholine receptor in chromaffin cells [183] and in rat pheochromocytoma cells [184], and to accelerate the desensitization at $\mathrm{GABA}_{\mathrm{A}}$ and glycine receptors in amacrine-like cells of carp (Carassius auratus) retina [192]. Moreover, 1,9-dideoxyforskolin (10 $\mu \mathrm{M})$ was reported to partially reverse the resistance to doxorubicin in multidrug resistance lines in a dose-dependent manner by enhancing the uptake of doxorubicin in resistant cells [187], to partially inhibit the in vitro proliferation of human airway smooth muscle cells [92], and to reduce the binding of platelet-activating factor to platelet receptors in isolated rabbit platelets [68]. In addition, 1,9-dideoxyforskolin was shown to enhance the activity of protein phosphatase $2 \mathrm{~A}$ (PP2A) and therefore restore its activity in the $\mathrm{BCR} / \mathrm{ABL}^{+}$cell line, which consequently leads to the impairment of the BCR/ABL leukemogenic potential in imatinib-sensitive and resistant cell lines. Similarly, the clonogenic potential of myeloid CML-BCCD34+ cells was also dramatically reduced by $1,9-$ dideoxyforskolin treatment (80-95\% inhibition). Importantly, in vivo administration of the PP2A activator 1,9-dideoxyforskolin severely impacted and efficiently modulated the development of the wild-type and T315I BCR/ABL-induced acute leukemia-like disease process [133].

FSK88, a forskolin derivative, extracted and purified from cultured roots, was reported to induce apoptotic death of human gastric cancer BGC 823 cells through multiple cellular and molecular pathways such as the upregulation of pro-apoptotic Bax and Bad gene expression and downregulation of anti-apoptotic Bc1-2 gene expression, dissipation of mitochondrial potential $\Delta \psi_{\mathrm{m}}$, mi- tochondrial release of cytochrome c, caspase-3 and caspase-9 activation [207].

13-Epi-9-deoxyforskolin (55) (see Fig. 3 in part 1 ) was reported to produce a blood pressure-lowering activity on anesthetized cats [208].

13-Epi-sclareol (59) (see Fig. 4 in part 1) was found to produce antiproliferative activity in breast and uterine cancers in vitro. The antiproliferative activity of 13 -epi-sclareol $\left(\mathrm{IC}_{50}: 11.056 \mu \mathrm{M}\right)$ in the breast cancer cell line MCF-7 was found to be comparable to that of tamoxifen ( $\mathrm{IC}_{50}: 14.34 \mu \mathrm{M}$ ) and devoid of cytotoxicity in normal cells, namely the Vero cell line and primary osteoblast cells. The compound also inhibited the growth of endometrial adenocarcinoma (Ishikawa) cells where tamoxifen failed to show any such effect. Moreover, 13-epi-sclareol $(10 \mu \mathrm{M}$ and $20 \mu \mathrm{M})$ showed concentration-dependent increased apoptotic changes in the breast cancer cell line MCF-7 [209].

Forskoditerpenosides A (64), B (65), C (66), D (67), E (68) (see Fig. 5 in part 1) were found to relax guinea pig tracheal spirals [204,210].

Barbatusin (6) (see Fig. 1 in part 1) was found to demonstrate an inhibitory effect against Lewis lung carcinoma and lymphocytic leukemia P 388 in mice [10].

Barbatusol (25) (see Fig. 1 in part 1), at a dose of $3 \mathrm{mg} / \mathrm{kg}$ (i.v. in rats), was found to induce a potent lowering of blood pressure associated with discrete bradycardy [6].

Coleon C (15) (see Fig. 1 in part 1) was reported to inhibit tumor growth and proliferation with a low toxicity to normal cells [211].

Plectrin (5) (see Fig. 1 in part 1) was reported to display antifeedant activity against the green bug Schizaphis graminum and the pink bollworm Pectinophora gossypiella [9].

Plectrinon A (12) (see Fig. 1 in part 1) was found to inhibit the gastric $\mathrm{H}^{+}, \mathrm{K}^{+}$-ATPase with an $\mathrm{IC}_{50}$ value about 10 -fold greater than that of the classic proton pump inhibitor omeprazole. This result may account for the antisecretory acid effect and reputed antiulcer activity of $P$. barbatus [15].

\section{Second generation forskolin derivatives}

Although the biological profile of forskolin is characterized by various pharmacological properties such as the positive inotropic, hypotensive, bronchospasmolytic and antiglaucoma activities that have been proved in vitro and in vivo using mainly laboratory animals and few humans, forskolin has not been available as an approved drug due to its low water solubility (ca. $0.001 \%$ ) [212] and low oral activity that limit its clinical usage as an intravenous formulation and an oral one, respectively [213], as well as the concern that forskolin as a nonspecific adenylyl cyclase activator may be too toxic for clinical use. Forskolin has, therefore, been considered as a useful prototype for the development of similar agents with better water solubility and more selective effects on adenylyl cyclase types. Several attempts were tried to increase the aqueous solubility of unmodified forskolin by dissolving it in solutions of solublizing agents such as $\alpha-, \beta$ - and $\gamma$-cyclodextrins and their derivatized products such as hydroxypropylgamma-cyclodextrin [212,214], and a block copolymer Pluronic F-127 [215]. The solubility of such forskolin solutions was increased to some extent and was found to be especially useful for topical application to treat intraocular pressure. Further synthetic and structure-activity studies, such as the introduction of water-soluble substituents onto forskolin, were carried out, and of the active analogues produced, the 6-(3-dimethylaminopropionyl) forskolin hydrochloride (NKH477) (79) (see Fig. 7 in part 
1) was found to be one of the more potent water-soluble forskolin derivatives [213,214,216,217]. NKH477, like forskolin, was also found to stimulate adenylyl cyclase directly and produce various cAMP-dependent pharmacological effects, for example, on cardiovascular, respiratory, renal, and immune systems [92,218-223]. In contrast to forskolin, NKH477 was shown to be orally active $[213,219]$, have a poor permeability through the blood-brain barrier [219] and have a significantly higher affinity for the adenylyl cyclase type V (a major isoform in the myocardium) [224,225], that may account for the notable pharmacological activities of NKH477 in the cardiovascular system.

In this review, we focus briefly on the cardiovascular effects of NKH477 and on some examples of its clinical applications for the treatment of cardiovascular diseases - as evaluating the wide-ranging pharmacological activities of NKH477 is beyond the scope of this review. In a number of in vivo and in vitro animal model studies, NKH477 was found to produce a similar cardiovascular profile (positive inotropic, positive chronotropic, and coronary vasodilatory effects) $[219,226,227]$ to that of forskolin, except for the duration of actions; in which, NKH477 was longeracting than forskolin [228]. In anesthetized dogs, NKH477 administered intravenously produced dose-related increases in left ventricular $\mathrm{dP} / \mathrm{dt}_{\max }$, cardiac output, coronary and femoral blood flow, heart rate and myocardial oxygen consumption, and doserelated decreases in blood pressure, pulmonary arterial diastolic pressure and total peripheral resistance $[213,229]$. In addition, in some animal heart failure models, NKH477 was reported to improve cardiac function [230,231]. Moreover, NKH477 was found to be effective on the $\beta$-receptor desensitized heart model in which the effects of $\beta$-adrenoceptor agonists and phosphodiesterase inhibitors were attenuated $[219,227,232]$. In clinical studies [227,233], an NKH477 infusion $(0.4$ to $0.8 \mu \mathrm{g} / \mathrm{kg} / \mathrm{min})$ was found to improve the hemodynamics as well as subjective and objective symptoms in patients with heart failure and was also effective in catecholamine-resistant heart failure patients. A number of clinical applications of NKH477 [Colforsin daropate HCl; (Adehl ${ }^{\circledR}$ Inj., Nihon Kayaku, Ltd., Tokyo, Japan)] - a recently available forskolin derivative in Japan [234,235] - has demonstrated the usefulness of NKH477 as the first clinically available adenylyl cyclase activator for preoperative management [234, $236,237]$ of patients undergoing cardiac surgery. Iranami et al. [235] reported a case in which the continuous infusion of NKH477 $\left(0.25 \mu \mathrm{g} \cdot \mathrm{kg}^{-1} \cdot \mathrm{min}^{-1}\right)$ successfully permitted the weaning of a neonate from cardiopulmonary bypass after correction of a complex congenital cardiac defect, under conditions in which better known inotropic agents [e.g., milrinone (phosphodiesterase inhibitor) in combination with epinephrine and isoproterenol] had failed. NKH477 administration to 9 patients after open heart surgery was found to improve the hemodynamics through positive inotropic and vasodilator effects without hypotension. However, side effects such as tachycardia and arrhythmia have been observed [238].

\section{Conclusion}

$\nabla$

The potential role of Plectranthus barbatus in traditional medicine - for the treatment of several diseases - and the disclosure of some of its pharmacological activities, has provoked the selection of this plant for strategically planned research programs starting in India and then in East Africa, Brazil and China over the past decades that have continued up to now, and led to the isolation of a number of new compounds including those with unusual structural and pharmacological profiles. Besides essential oils, 25 abietane diterpenoids and 43 labdane diterpenoids were the main constituents isolated from different parts of $P$. barbatus. The pharmacological profile of the constituents is wide ranging, and could justify the ethnobotanical uses of $P$. barbatus. The essential oils were found to have antimicrobial and spasmolytic activities, some of the abietane diterpenoids such as barbatusin, coleon $\mathrm{C}$ were characterized by antitumor activity, barbtusol by a hypotensive effect, plectrinon $A$ by a gastric proton pump inhibitory effect and plectrin by an antifeedant activity. Of the 43 labdane diterpenoids, 27 were distinguished by the typical 8,13epoxy-labd-14-en-11-one skeleton, among them forskolin was found to possess the optimal structural requirements for a direct, high activation of adenylyl cyclase. Forskolin was therefore the most important and extensively studied compound. The unique character of forskolin, as a direct activator of adenylyl cyclase, was considered to account for the broad in vivo and vitro, proven pharmacological activities of the compound. However, the low aqueous solubility and low oral bioavailability and the nonspecific activation of adenylyl cyclase prevent forskolin from being clinically used. Nevertheless, forskolin remains, so far, a valuable tool to study the role of cAMP in cellular processes. Compared to forskolin, NKH477 [6-(3-dimethylaminopropionyl) forskolin hydrochloride], a synthetic water-soluble forskolin derivative, has better characteristics as it is orally and intravenously active and possesses high affinity for adenylyl cyclase, especially type $\mathrm{V}$ in the myocardium. Many in vivo, in vitro, animal models and clinical studies have provided experimental evidence indicating that NKH477 is effective as a cardiotonic and vasodilator. NKH477 [Colforsin daropate $\mathrm{HCl}$; (Adehl $\left.{ }^{\circledR} I n j.\right)$ ] is available as an approved drug in Japan and is used for the treatment of heart failure. This review illustrates an example of how the selection of a proper plant for a planned mission-oriented research can lead to the development of a potential drug.

\section{References}

1 Matu EN, van Staden J. Antibacterial and anti-inflammatory activities of some plants used for medicinal purposes in Kenya. J Ethnopharmacol 2003; 87: 35-41

2 Runyoro DKB, Matee MIN, Ngassapa OD, Joseph CC, Mbwambo ZH. Screening of Tanzanian medicinal plants for anti-Candida activity. BMC Complement Altern Med 2006; 6: 11

3 Tamasiro V, Davino SC, Freitas PCD, Barros SBM. In vitro antioxidant activity of Coleus barbatus (Andr.) Benth (false boldo) and Peumus boldo (Molina) (Boldo do Chile): a comparative study. Rev Farm Bioquim Univ Sao Paulo 1998; 34: 15-17

4 Costa MCCD, Nascimento SC. Actividade citotóxica de Plectranthus barbatus Andr. (Lamiaceae). Acta Farm Bonaer 2003; 22: 155-158

5 de Souza NJ, Dohadwalla AN, Reden J. Forskolin: a labdane diterpenoid with antihypertensive, positive inotropic, platelet aggregation inhibitory, and adenylate cyclase activating properties. Med Res Rev 1983; 3: 201-219

6 Kelecom A. Isolation, structure determination, and absolute configuration of barbatusol, a new bioactive diterpene with a rearranged abietane skeleton from the labiate Coleus barbatus. Tetrahedron 1983; 39: 3603-3608

7 Bhakuni DS, Dhar ML, Dhar MM, Dhawan BN, Gupta B, Srimal RC. Screening of Indian plants for biological activity. Indian J Exp Biol 1971; 9: 91

8 Staudinger JL, Ding X, Lichti K. Pregnane X receptor and natural products: beyond drug-drug interactions. Expert Opin Drug Metab Toxicol 2006; 2: 847-857

9 Kubo I, Matsumoto T, Tori M, Asakawa Y. Structure of plectrin, an aphid antifeedant diterpene from Plectranthus barbatus. Chem Lett 1984; 9: 1513-1516 
10 Zelnik R, Lavie D, Levy EC, Wang AHJ, Paul IC. Barbatusin and cyclobutatusin, two novel diterpenoids from Coleus barbatus Bentham. Tetrahedron 1977; 33: 1457-1467

11 Yadava JNS, Gupta S, Ahmad I, Varma N, Tandon JS. Neutralization of enterotoxins of Escherichia coli by coleonol (forskolin) in rabbit and guinea pig ileal loop models. Indian J Anim Sci 1995; 65: 1177-1181

12 Almeida FC, Lemonica IP. The toxic effects of Coleus barbatus B on the different periods of pregnancy in rats. J Ethnopharmacol 2000; 73 : $53-60$

13 Camara CC, Nascimento NR, Macedo-Filho CL, Almeida FB, Fonteles MC. Antispasmodic effect of the essential oil of Plectranthus barbatus and some major constituents on the guinea-pig ileum. Planta Med 2003; 69: $1080-1085$

14 Fischman LA, Skorupa LA, Souccar C, Lapa AJ. The water extract of Coleus barbatus Benth decreases gastric secretion in rats. Mem Inst Oswaldo Cruz 1991; 86 (Suppl. 2): 141-143

15 Schultz C, Bossolani MP, Torres LMB, Lima-Landman MTR, Lapa AJ, Souccar $\mathrm{C}$. Inhibition of the gastric $\mathrm{H}^{+}, \mathrm{K}+-$ ATPase by plectrinone $\mathrm{A}$, a diterpenoid isolated from Plectranthus barbatus Andrews. J Ethnopharmacol 2007; $111: 1-7$

16 Battochio AP, Sartori MS, Coelho CA. Water-soluble extract of Coleus barbatus modulates weight gain, energy utilization and lipid metabolism in secondary biliary cirrhosis: an experimental study in young rats. Acta Cir Bras 2005; 20: 229-236

17 Han LK, Morimoto C, Yu RH, Okuda H. Effects of Coleus forskohlii on fat storage in ovariectomized rats. Yakugaku Zasshi 2005; 125: 449-453

18 Zhang R, Kong L, Wang G, Zuo G. Manufacture of dripping pills containing Coleus forskohlii extract. Chinese Patent CN 1682840 A; 2005

19 Liu J, Zhang J, Chen Z, Xu YL, Jin QD. Chinese medicine composition for treating asthma and cough and its preparation. Chinese Patent CN 1872146 A; 2006

20 Jin $Q$ Chen Z, Zhang G. A Chinese medicinal granule for treating bronchial asthma containing flos colei esquirolii, radix peucedani, and radix glycyrrhizae. Chinese Patent CN 1154861 A; 1997

21 Tanaka $R$. Dentifrice compositions containing taurine and Coleus forskohlii extract. Japanese Patent JP 2003171250 A; 2003

22 Godard MP, Johnson BA, Richmond SR. Body composition and hormonal adaptations associated with forskolin consumption in overweight and obese men. Obes Res 2005; 13: 1335-1343

23 Badmaev V, Majeed $H$. Compositions for physiological increase of male and female hormones with diterpene forskolin and its derivatives. Patent Application No. AU 2007200442 A1; 2007

24 Yamashita A, Takashita T, Ishihara T. Antiobesity agents and food, beverage, and medical compositions containing bergenin and forskolin and/or astilbin. Japanese Patent JP 2004091464 A; 2004

25 Miura $M$. Foods containing $\alpha$-glucosidase inhibitors for restricting calories. Japanese Patent JP 2007195510 A; 2007

26 Saito $M$, Hara $M$, Hirotsu S. Lipid decomposition promoters and cosmetics containing plant extracts. Japanese Patent JP 2000016916 A; 2000

27 Kawakami T. Anti-allergy compositions containing Coleus forskohlii root extract and cinnamon extract. Japanese Patent JP 2003252786 A; 2003

28 Bonte F, Meybeck A, Marechal C. Composition based on hydrated lipidic lamellar phases or on liposomes containing at least one derivative of labdane, or a plant extract containing it; cosmetic or pharmaceutical, particularly dermatological composition containing it. US Patent 5891464; 1999

29 Adachi H, Ehata S, Hayashi T. Antiaging cosmetics containing Coleus forskohlii root extracts and antioxidants. Japanese Patent JP 08176005 A; 1996

30 Majeed M, Prakash S. Composition and methods containing an antimicrobial essential oil extended from Coleus forskohlii. US Patent 6607712 B2; 2003

31 Lukhoba CW, Simmonds MSJ, Paton AJ. Plectranthus: a review of ethnobotanical uses. J Ethnopharmacol 2006; 103: 1-24

32 Seamon KB, Padgett W, Daly JW. Forskolin: unique diterpene activator of adenylate cyclase in membranes and in intact cells. Proc Natl Acad Sci USA 1981; 78: 3363-3367

33 Daly JW, Padgett W, Seamon KB. Activation of cyclic AMP-generating systems in brain membranes and slices by the diterpene forskolin: augmentation of receptormediated responses. J Neurochem 1982; 38: 532-544

34 Fradkin JE, Cook GH, Kilhoffer MC, Wolff J. Forskolin stimulation of thyroid adenylate cyclase and cyclic 3',5'-adenosine monophosphate accumulation. Endocrinology 1982; 111: 849-856
35 Birnbaumer L, Stengel D, Desmier M, Hanoune J. Forskolin regulation of liver membrane adenylyl cyclase. Eur J Biochem 1983; 136: 107-112

36 Mettauer M, Giesen EM, Imbs JL, Schmidt M, Schwartz J. Forskolin increases cAMP production in a kidney cell line (MDCK). Libr Compend 1983; 11: 887

37 Seamon KB, Daly JW, Metzger H, de Souza NJ, Reden J. Structure-activity relationships for activation of adenylate cyclase by the diterpene forskolin and its derivatives. J Med Chem 1983; 26: 436-439

38 Seamon $K B$, Wetzel $B$. Interaction of forskolin with dually regulated adenylate cyclase. Adv Cyclic Nucleotide Protein Phosphorylation Res 1984; 17: 91-99

39 Seamon KB. Forskolin and adenylate cyclase: new opportunities in drug design. Annu Rep Med Chem 1984; 19: 293-302

40 Daly JW. Forskolin, adenylate cyclase, and cell physiology: an overview. Adv Cyclic Nucleotide Protein Phosphorylation Res 1984; 17: 81-89

41 Seamon KB. Activation of hormone-sensitive adenylate cyclase by forskolin. Drug Dev Res 1985; 6: 181-192

42 Seamon KB. Forskolin and adenylate cyclase. ISI atlas of science. Pharmacology 1987; 1: 250-253

43 Pfeuffer E, Mollner S, Pfeuffer T. Adenylate cyclase from bovine brain cortex: purification and characterization of the catalytic unit. EMBO J 1985; 4: 3675-3679

44 Smigel MD. Purification of the catalyst of adenylate cyclase. J Biol Chem 1986; 261: 1976-1982

45 Hacker BM, Tomlinson JE, Wayman GA, Sultana R, Chan G, Villacres E, Disteche C, Storm DR. Cloning, chromosomal mapping, and regulatory properties of the human type 9 adenylyl cyclase (ADCY9). Genomics 1998; 50: 97-104

46 Defer N, Best-Belpomme M, Hanoune J. Tissue specificity and physiological relevance of various isoforms of adenylyl cyclase. Am J Physiol Renal Physiol 2000; 279: F400-F416

47 Dahle MK, Myhre AE, Aasen AO, Wang JE. Effects of forskolin on Kupffer cell production of interleukin-10 and tumor necrosis factor alpha differ from those of endogenous adenylyl cyclase activators: possible role for adenylyl cyclase 9. Infect Immun 2005; 73: 7290-7296

48 Ammon HP, Müller AB. Forskolin: from an ayurvedic remedy to a modern agent. Planta Med 1985; 51: 473-477

49 Bhat SV, Dohadwalla AN, Bajwa BS, Dadkar NK, Dornauer H, de Souza NJ. The antihypertensive and positive inotropic diterpene forskolin: effects of structural modifications on its activity. J Med Chem 1983; 26 486-492

50 Lindner E, Metzger $H$. The action of forskolin on muscle cells is modified by hormones, calcium ions and calcium antagonists. Arzneimittelforschung 1983; 33: 1436-1441

51 Iwase M, Ishikawa Y, Shen YT, Shannon RP, Sato N, Ganguly PK, Eki T, Vatner DF, Vatner SF. Neurally mediated cardiac effects of forskolin in conscious dogs. Am J Physiol 1996; 271: H1473-H1482

52 Abe A, Karaki $\mathrm{H}$. Effect of forskolin on cytosolic $\mathrm{Ca}^{++}$level and contraction in vascular smooth muscle. J Pharmacol Exp Ther 1989; 249: 895900

53 Rembold CM, Chen XL. Mechanisms responsible for forskolin-induced relaxation of rat tail artery. Hypertension 1998; 3: 872-877

54 White RE, Kryman JP, El-Mowafy AM, Han G, Carrier GO. cAMP-dependent vasodilators cross-activate the cGMP-dependent protein kinase to stimulate BKCa channel activity in coronary artery smooth muscle cells. Circ Res 2000; 86: 897-905

55 Linz W, Wiemer G, Schölkens BA. Effects of colforsin, trequinsin and isoprenaline on norepinephrine-induced contractions and cyclic nucleotide levels of isolated vascular tissue. Arzneimittelforschung 1988; 38: 240-243

56 Bristow MR, Ginsburg R, Strosberg A, Montgomery W, Minobe W. Pharmacology and inotropic potential of forskolin in the human heart. J Clin Invest 1984; 74: 212-223

57 Kramer W, Thormann J, Kindler M, Schlepper M. Effects of forskolin on left ventricular function in dilated cardiomyopathy. Arzneimittelforschung 1987; 37: 364-367

58 Baumann G, Felix S, Sattelberger U, Klein G. Cardiovascular effects of forskolin (HL 362) in patients with idiopathic congestive cardiomyopathy - a comparative study with dobutamine and sodium nitroprusside. J Cardiovasc Pharmacol 1990; 16: 93-100

59 Vaden SL, Adams HR. Inotropic, chronotropic and coronary vasodilator potency of forskolin. Eur J Pharmacol 1985; 118: 131-137

60 Wysham DG, Brotherton AF, Heistad DD. Effects of forskolin on cerebral blood flow: implications for a role of adenylate cyclase. Stroke 1986; 17: $1299-1303$ 
61 Agarwal KC, Zielinski BA, Maitra RS. Significance of plasma adenosine in the antiplatelet activity of forskolin: potentiation by dipyridamole and dilazep. Thromb Haemost 1989; 61: 106-110

62 Graber SE, Hawiger J. Evidence that changes in platelet cyclic AMP levels regulate the fibrinogen receptor on human platelets. J Biol Chem 1982; 257: 14606-14609

63 Kariya T, Morito F, Sakai T, Takahata K, Yamanaka M. Effect of forskolin on platelet deaggregation and cyclic AMP generation. Naunyn Schmiedebergs Arch Pharmacol 1985; 331: 119-121

64 Salim MLD. Effect of aspirin and forskolin on blood platelet function. Alex J Pharm Sci 2003; 17: 151-155

65 de Chaffoy de Courcelles D, Roevens P, Van Belle H. Prostaglandin E1 and forskolin antagonize C-kinase activation in the human platelet. Biochem J 1987; 244: 93-99

66 Doni MG, Deana R, Bertoncello S, Zoccarato F, Alexandre A. Forskolin and prostacyclin inhibit fluoride induced platelet activation and protein kinase C dependent responses. Biochem Biophys Res Commun 1988; 156: $1316-1323$

67 Russo I, Doronzo G, Mattiello L, De Salve A, Trovati M, Anfossi G. The activity of constitutive nitric oxide synthase is increased by the pathway cAMP/cAMP-activated protein kinase in human platelets. New insights into the antiaggregating effects of cAMP-elevating agents. Thromb Res 2004; 114: 265-273

68 Wong S, Mok W, Phaneuf S, Katz S, Salari H. Forskolin inhibits plateletactivating factor binding to platelet receptors independently of adenylyl cyclase activation. Eur J Pharmacol 1993; 245: 55-61

69 Agarwal KC, Parks Jr RE. Forskolin: a potential antimetastatic agent. Int J Cancer 1983; 32: 801-804

70 Yoshizawa J, Yoshida K, Fujikawa T, Tanabe A, Sakurai K. Inhibitory effects of forskolin on hepatic metastasis from human colon cancer in nude mice. Nippon Geka Gakkai Zasshi 1995; 96: 26-30

71 Thulesius 0 , Christenson JT. Methods for preventing thrombosis; and surgical implant having reduced platelet deposition characteristics. US Patent 4909799; 1990

72 Siegl AM, Moroff G. Effect of forskolin on the maintenance of platelet properties during storage. J Lab Clin Med 1986; 108: 354-359

73 Chang J, Hand JM, Schwalm S, Dervinis A, Lewis AJ. Bronchodilating activity of forskolin in vitro and in vivo. Eur J Pharmacol 1984; 101: 271274

74 Kreutner W, Chapman RW, Gulbenkian A, Tozzi S. Bronchodilator and antiallergy activity of forskolin. Eur J Pharmacol 1985; 111: 1-8

75 Tsukawaki M, Suzuki K, Suzuki R, Takagi K, Satake T. Relaxant effects of forskolin on guinea pig tracheal smooth muscle. Lung 1987; 165: 225237

76 Yousif MHM, Thulesius O. A pharmacological study of bronchodilator properties of NKH477, forskolin, and $\beta$-agonists on guinea pig and ovine isolated bronchioles. Drug Dev Res 2000; 51: 169-176

77 Yousif $M H$, Thulesius 0 . Forskolin reverses tachyphylaxis to the bronchodilator effects of salbutamol: an in-vitro study on isolated guineapig trachea. J Pharm Pharmacol 1999; 51: 181-186

78 Kreutner W, Green MJ, Shue H-J, Saksena AK. Method for treating allergic reactions with forskolin. US Patent 4782082; 1988

79 Lichey I, Friedrich T, Priesnitz M, Biamino G, Usinger P, Huckauf H. Effect of forskolin on methacholine-induced bronchoconstriction in extrinsic asthamtics. Lancet 1984; 2: 167

80 Kaik G, Witte PU. Protective effect of forskolin in acetylcholine provocation in healthy probands. Comparison of 2 doses with fenoterol and placebo. Wien Med Wochenschr 1986; 136: 637-641

81 González-Sánchez R, Trujillo X, Trujillo-Hernández B, Vásquez C, Huerta $M$, Elizalde A. Forskolin versus sodium cromoglycate for prevention of asthma attacks: a single-blinded clinical trial. J Int Med Res 2006; 34 : 200-207

82 Bauer K, Dietersdorfer F, Sertl K, Kaik B, Kaik G. Pharmacodynamic effects of inhaled dry powder formulations of fenoterol and colforsin in asthma. Clin Pharmacol Ther 1993; 53: 76-83

83 Yang CM, Pan SL, Chiu CT, Lin CC, Hsu YM. Effect of forskolin on endothelin-induced phosphoinositide hydrolysis and calcium mobilization in cultured canine tracheal smooth muscle cells. J Auton Pharmacol 1998; 18: 213-221

84 Schramm CM, Chuang ST, Grunstein MM. cAMP generation inhibits inositol 1,4,5-trisphosphate binding in rabbit tracheal smooth muscle. Am J Physiol 1995; 269: L715-L719

85 Zhu S, White RE, Barman SA. Effect of PKC isoenzyme inhibition on forskolin-induced activation of BKCa channels in rat pulmonary arterial smooth muscle. Lung 2006; 184: 89-97
86 Bai Y, Sanderson MJ. Airway smooth muscle relaxation results from a reduction in the frequency of $\mathrm{Ca}^{2+}$ oscillations induced by a cAMPmediated inhibition of the $\mathrm{IP}_{3}$ receptor. Respir Res 2006; 7: 34

87 Tajimi M, Hori M, Mitsui M, Ozaki H, Karaki H. Inhibitory effect of forskolin on myosin phosphorylation-dependent and independent contractions in bovine tracheal smooth muscle. J Smooth Muscle Res 1995; 31: 129-142

88 Tolloczko B, Jia YL, Martin JG. Effects of cAMP on serotonin evoked calcium transients in cultured rat airway smooth muscle cells. Am J Physiol 1997; 272: L865-L871

89 Sakai J, Oike M, Hirakawa M, Ito Y. Theophylline and cAMP inhibit lysophosphatidic acid-induced hyperresponsiveness of bovine tracheal smooth muscle cells. J Physiol 2003; 549: 171-180

90 Kaur M, Holden NS, Wilson SM, Sukkar MB, Chung KF, Barnes PJ, Newton R, Giembycz MA. Effect of beta2-adrenoceptor agonists and other cAMP-elevating agents on inflammatory gene expression in human ASM cells: a role for protein kinase A. Am J Physiol Lung Cell Mol Physiol 2008; 295: L505-L514

91 Musa NL, Ramakrishnan M, Li J, Kartha S, Liu P, Pestell RG, Hershenson $M B$. Forskolin inhibits cyclin D1 expression in cultured airway smooth-muscle cells. Am J Respir Cell Mol Biol 1999; 20: 352-358

92 Kassel KM, Wyatt TA, Panettieri Jr RA, Toews ML. Inhibition of human airway smooth muscle cell proliferation by $\beta$-2-adrenergic receptors and cAMP is PKA independent: evidence for EPAC involvement. Am J Physiol Lung Cell Mol Physiol 2008; 294: L131-L138

93 Prostran M, Varagić VM. The effect of forskolin on the isometric contraction of the isolated hemidiaphragm of the rat. $\mathrm{Br} J$ Pharmacol 1986; 88: 791-797

94 Takahashi S, Moriwaki K, Himeno S, Kuroshima T, Shinomura Y, Hamabe S, Kurokawa M, Saito R, Kitani T, Tarui S. Forskolin-induced cyclic AMP production and gastric acid secretion in dispersed rabbit parietal cells: novel evidence for a major role of cyclic AMP in acid release. Life Sci 1983; 33: 1401-1408

95 Choquet A, Magous R, Galleyrand JC, Bali JP. Is forskolin a stimulant of gastric secretion? C R Seances Soc Biol Fil 1988; 182: 335-343

96 Hersey SJ, Miller M, Norris SH. Forskolin: a new biochemical tool for studying gastric secretion. Prog Clin Biol Res 1983; 126: 329-341

97 Hersey SJ, Owirodu A, Miller M. Forskolin stimulation of acid and pepsinogen secretion by gastric glands. Biochim Biophys Acta 1983; 755: 293-299

98 Modlin IM, Schafer DE, Tyshkov M, Ballantyne GH, Fratesi GR, Roberts $J R, Z$ don MJ. Forskolin (cyclic adenosine monophosphate)-dependent protein phosphorylation in isolated gastric glands. Arch Surg 1986; 121: 330-337

99 Iwatsuki K, Horiuchi A, Yamagishi F, Chiba S. Effects of forskolin on pancreatic exocrine secretion and cyclic nucleotide concentrations of the dog pancreas. Arch Int Pharmacodyn Ther 1987; 286: 320-328

100 Dubey MP, Srimal RC, Nityanand S, Dhawan BN. Pharmacological studies on coleonol, a hypotensive diterpene from Coleus forskohlii. J Ethnopharmacol 1981; 3: 1-13

101 Mimura M. Functional food for the bowel movement improvement. Japanese Patent JP 2007097572 A; 2007

102 Morita T, Wheeler MA, Miyagawa I, Kondo S, Weiss RM. Effects of forskolin on contractility and cyclic AMP levels in rabbit detrusor muscle. Tohoku J Exp Med 1986; 149: 283-285

103 Truss MC, Uckert S, Stief CG, Kuczyk M, Schulz-Knappe P, Forssmann $W G$, Jonas $U$. Effects of various phosphodiesterase-inhibitors, forskolin, and sodium nitroprusside on porcine detrusor smooth muscle tonic responses to muscarinergic stimulation and cyclic nucleotide levels in vitro. Neurourol Urodyn 1996; 15: 59-70

104 Schwertschlag $U$, Hackenthal E. Forskolin stimulates renin release from the isolated perfused rat kidney. Eur J Pharmacol 1982; 84: 111-113

105 Bishop BL, Duncan MJ, Song J, Li G, Zaas D, Abraham SN. Cyclic AMPregulated exocytosis of Escherichia coli from infected bladder epithelial cells. Nat Med 2007; 13: 625-630

106 Vedernikov YP, Syal AS, Okawa T, Saade GR, Garfield RE. Adenylate cyclase and potassium channels are involved in forskolin- and 1,9-dideoxyforskolin-induced inhibition of pregnant rat uterus contractility. Am J Obstet Gynecol 2000; 182: 620-624

107 Tamaki T, Hasui K, Shoji T, Aki Y, Kiyomoto H, Iwao H, Abe Y. Forskolin preferentially dilates the afferent arteriole in the canine kidney. Jpn J Pharmacol 1991; 55: 161-164

108 Caprioli J, Sears M. Forskolin lowers intraocular pressure in rabbits, monkeys, and man. Lancet 1983; 1: 958-960 
109 Caprioli J, Sears M, Bausher L, Gregory D, Mead A. Forskolin lowers intraocular pressure by reducing aqueous inflow. Invest Ophthalmol Vis Sci 1984; 25: 268-277

110 Burstein NL, Sears ML, Mead A. Aqueous flow in human eyes is reduced by forskolin, a potent adenylate cyclase activator. Exp Eye Res 1984; 39: 745-749

111 Caprioli J, Sears $M$. The adenylate cyclase receptor complex and aqueous humor formation. Yale J Biol Med 1984; 57: 283-300

112 Sears ML. Regulation of aqueous flow by the adenylate cyclase receptor complex in the ciliary epithelium. Am J Ophthalmol 1985; 100: 194-198

113 Bartels SP, Lee SR, Neufeld AH. Forskolin stimulates cyclic AMP synthesis, lowers intraocular pressure and increases outflow facility in rabbits. Curr Eye Res 1982/1983; 2: 673-681

114 Ramachandran C, Satpathy M, Mehta D, Srinivas SP. Forskolin induces myosin light chain dephosphorylation in bovine trabecular meshwork cells. Curr Eye Res 2008; 33: 169-176

115 Bartels SP, Lee SR, Neufeld AH. The effects of forskolin on cyclic AMP, intraocular pressure and aqueous humor formation in rabbits. Curr Eye Res 1987; 6: 307-320

116 Lee PY, Podos SM, Serle JB, Camras CB, Severin CH. Intraocular pressure effects of multiple doses of drugs applied to glaucomatous monkey eyes. Arch Ophthalmol 1987; 105: 249-252

117 Matsumoto S, Yamashita T, Araie M, Kametani S, Hosokawa T, Takase $M$. The ocular penetration of topical forskolin and its effects on intraocular pressure, aqueous flow rate and cyclic AMP level in the rabbit eye. Jpn J Ophthalmol 1990; 34: 428-435

118 Santana C, Menendez-Pelaez A, Reiter RJ, Guerrero JM. Treatment with forskolin for 8 hours during the day increases melatonin synthesis in the Syrian hamster pineal gland in organ culture: the long lag period is required for RNA synthesis. J Neurosci Res 1990; 25: 545-548

119 Michelet JF, Gautier B, Gaillard O, Bernard BA, Benech F. Human hair follicle pigmentary unit as a direct target for modulators of melanogenesis, as studied by [C]-2-thiouracil incorporation. Exp Dermatol 2009; 18: 414-416

120 Nishizawa H, Kono T, Yokoyama D, Masuda M. Effects of forskolin on hair follicular keratinocytes. Nippon Koshohin Kagakkaishi 2000; 24: $111-114$

121 Hayashi T. Application of a new botanical ingredient 'Coleus extract' to hair growth products. Fragr J 2000; 28: 45-49

122 Majeed M. Compositions and methods to treat alopecia. US Pat Appl Publ US 2008/0241285 A1; 2008

123 Lal B, Blumbach J, Dohadwalla AN, de Souza NJ. Pharmaceutical compositions comprising labdane diterpenoid derivatives and pyrimido $[6,1-a]$ isoquinolin-4-one derivatives and their use. US Patent 5141942; 1992

124 D’Orazio JA, Nobuhisa T, Cui R, Arya M, Spry M, Wakamatsu K, Igras V, Kunisada T, Granter SR, Nishimura EK, Ito S, Fisher DE. Topical drug rescue strategy and skin protection based on the role of Mc1 $\mathrm{r}$ in UV-induced tanning. Nature 2006; 443: 340-344

125 Passeron T, Namiki T, Passeron HJ, Le Pape E, Hearing VJ. Forskolin protects keratinocytes from UVB-induced apoptosis and increases DNA repair independent of its effects on melanogenesis. J Invest Dermatol 2009; 129: 162-166

126 Majeed M. Compositions and methods to effect enhanced photoprotection against UV A and UV B induced damage of human skin. US Pat Appl Publ US 2008/0226571 A1; 2008

127 Halprin KM, Adachi K. Treatment of hyperplastic diseases of the skin with polyoxygenated labdanes. PCT Int Appl WO 8503637 A1; 1985

128 Piontek M, Hengels KJ, Porschen R, Strohmeyer G. Protein kinase C and adenylate cyclase as targets for growth inhibition of human gastric cancer cells. J Cancer Res Clin Oncol 1993; 119: 697-699

129 Gützkow KB, Naderi S, Blomhoff HK. Forskolin-mediated G1 arrest in acute lymphoblastic leukemia cells: phosphorylated pRB sequesters E2Fs. J Cell Sci 2002; 115: 1073-1082

130 Guan K, Liu H, Tan W. Relationship between expression of Ha-ras and inhibition of proliferation by forskolin in human gastric cancer cell line BGC-823. Shengwu Huaxue Zazhi 1995; 11: 401-405

131 Guan K, Liu H, Tan W. The effect of forskolin on protein kinase C and its subunits in human gastric cancer cell line BGC-823. Shengwu Huaxue Zazhi 1995; 11: 316-320

132 Wang X, Zhang L, Zhao S, Ma L. Effects of forskolin on cell proliferation in human gastric cancer cells. Zhongliu Fangzhi Zazhi 2003; 10: 928930
133 Neviani P, Santhanam R, Trotta R, Notari M, Blaser BW, Liu S, Mao H, Chang JS, Galietta A, Uttam A, Roy DC, Valtieri M, Bruner-Klisovic R, Caligiuri MA, Bloomfield CD, Marcucci G, Perrotti D. The tumor suppressor PP2A is functionally inactivated in blast crisis CML through the inhibitory activity of the BCR/ABL-regulated SET protein. Cancer Cell 2005; 8: 355-368

134 McEwan DG, Brunton VG, Baillie GS, Leslie NR, Houslay MD, Frame MC Chemoresistant KM12C colon cancer cells are addicted to low cyclic AMP levels in a phosphodiesterase 4-regulated compartment via effects on phosphoinositide 3-kinase. Cancer Res 2007; 67: 5248-5257

135 Zhang $D$, Ye C, Wang $H$. Antitumor composition containing forskolin, theophylline, IBMX and carboxyamidotriazole. Chinese Patent $\mathrm{CN}$ 1660434 A; 2005

136 García-Bermejo L, Pérez C, Vilaboa NE, de Blas E, Aller P. cAMP increasing agents attenuate the generation of apoptosis by etoposide in promonocytic leukemia cells. J Cell Sci 1998; 111: 637-644

137 Watabe M, Masuda Y, Nakajo S, Yoshida T, Kuroiwa Y, Nakaya M. The cooperative interaction of two different signaling pathways in response to bufalin induces apoptosis in human leukemia U937 cells. J Biol Chem 1996; 271: 14067-14073

138 Wu SI, Ma J, Qi HI, Zhang Y, Zhang XY, Chen HI. Forskolin up-regulates metastasis-related phenotypes and molecules via protein kinase $\mathrm{B}$ but not PI-3K, in H7721 human hepato-carcinoma cell line. Mol Cell Biochem 2003; 254: 193-202

139 Burns TW, Langley PE, Terry BE, Bylund DB, Forte LR. Alpha-2 adrenergic activation inhibits forskolin-stimulated adenylate cyclase activity and lipolysis in human adipocytes. Life Sci 1982; 31: 815-821

140 Okuda H, Morimoto C, Tsujita T. Relationship between cyclic AMP production and lipolysis induced by forskolin in rat fat cells. J Lipid Res 1992; 33: 225-231

141 Mooney RA, Swicegood CL, Marx RB. Coupling of adenylate cyclase to lipolysis in permeabilized adipocytes: direct evidence that an antilipolytic effect of insulin is independent of adenylate cyclase. Endocrinology 1986; 119: 2240-2248

142 Litosch I, Hudson TH, Mills I, Li SY, Fain JN. Forskolin as an activator of cyclic AMP accumulation and lipolysis in rat adipocytes. Mol Pharmacol 1982; 22: 109-115

143 Allen DO, Ahmed B, Naseer K. Relationships between cyclic AMP levels and lipolysis in fat cells after isoproterenol and forskolin stimulation. J Pharmacol Exp Ther 1986; 238: 659-664

144 Allen DO, Quesenberry JT. Quantitative differences in the cyclic AMPlipolysis relationships for isoproterenol and forskolin. J Pharmacol Exp Ther 1988; 244: 852-858

145 Schimmel RJ. Stimulation of cAMP accumulation and lipolysis in hamster adipocytes with forskolin. Am J Physiol 1984; 246: C63-C68

146 Morimoto C, Kameda K, Tsujita T, Okuda H. Relationships between lipolysis induced by various lipolytic agents and hormone-sensitive lipase in rat fat cells. J Lipid Res 2001; 42: 120-127

147 Majeed M, Bammi RK, Sankaran N, Ramanujam R, Kalkunte SS, Prakash $S$. Method of preparing labdane diterpene composition, preferably isoforskolin and deacetylforskolin from forskolin extract and their use for promoting lean body mass and other applications. US Pat Appl Publ US 2006122261 A1; 2006

148 Greenway FL, Bray GA. Regional fat loss from the thigh in obese women after adrenergic modulation. Clin Ther 1987; 9: 663-669

149 Greenway FL, Bray GA, Heber D. Topical fat reduction. Obes Res 1995; 3 (Suppl. 4): 561S-568S

150 Furukawa Y, Matsumori A, Hirozane T, Matsui S, Sato Y, Ono K, Sasayama S. Immunomodulation by an adenylate cyclase activator, NKH477, in vivo and vitro. Clin Immunol Immunopathol 1996; 79: 25-35

151 Schorlemmer HU, Dickneite G, Sedlacek HH, de Souza NJ, Dohadwalla $A N$. Use of the diterpene derivative forskolin for immunostimulation. US Patent 4578399; 1986

152 Curtin BF, Pal N, Gordon RK, Nambiar MP. Forskolin, an inducer of cAMP, upregulates acetylcholinesterase expression and protects against organophosphate exposure in neuro 2A cells. Mol Cell Biochem 2006; 290: 23-32

153 Morazzoni P, Bombardelli E. Use of forskolin or extracts containing it in the manufacture of a medicament for the treatment of alcohol addiction. PCT Int Appl WO 9636332 A1; 1996

154 Karaçay B, Li G, Pantazis NJ, Bonthius DJ. Stimulation of the cAMP pathway protects cultured cerebellar granule neurons against alcohol-induced cell death by activating the neuronal nitric oxide synthase (nNOS) gene. Brain Res 2007; 1143: 34-45 
155 Gupta PP, Srimal RC, Verma N, Tandon JS. Passive cutaneous anaphylactic inhibitory and mast cell stabilizing activity of coleonol and its derivative. Indian J Pharmacol 1994; 26: 150-152

156 Marone G, Columbo M, Triggiani M, Cirillo R, Genovese A, Formisano S. Inhibition of IgE-mediated release of histamine and peptide leukotriene from human basophils and mast cells by forskolin. Biochem Pharmacol 1987; 36: 13-20

157 Dohadwalla AN, Mandrekar SS, Dadkar NK, Khandelwal Y, Rupp RH, de Souza NJ. Labdane derivatives and their use as drugs. Patent DE 3502686 A1; 1986

158 Dohadwalla AN, Mandrekar SS, Dadkar NK, Khandelwal Y, Rupp RH, de Souza NJ. Method of treating inflammatory diseases with labdan derivatives. US Patent 4724238; 1988

159 Maeda H, Ozawa H, Saito T, Irie T, Takahata N. Potential antidepressant properties of forskolin and a novel water-soluble forskolin (NKH477) in the forced swimming test. Life Sci 1997; 61: 2435-2442

160 Sano M, Seto-Ohshima A, Mizutani A. Forskolin supresses seizures induced by pentylenetetrazole in mice. Experientia 1984; 40: 12701271

161 Barraco RA, Phillis JW, Altman HJ. Depressant effect of forskolin on spontaneous locomotor activity in mice. Gen Pharmacol 1985; 16 : 521-524

162 Bersudsky Y, Kotler M, Shifrin M, Belmaker RH. A preliminary study of possible psychoactive effects of intravenous forskolin in depressed and schizophrenic patients. Short communication. J Neural Transm 1996; 103: 1463-1467

163 Vitolo OV, Sant'Angelo A, Costanzo V, Battaglia F, Arancio O, Shelanski $M$. Amyloid beta-peptide inhibition of the PKA/CREB pathway and long-term potentiation: reversibility by drugs that enhance cAMP signaling. Proc Natl Acad Sci USA 2002; 99: 13217-13221

164 Wang X, Li X, Wang K, Zhou H, Xue B, Li L, Wang X. Forskolin cooperating with growth factor on generation of dopaminergic neurons from human fetal mesencephalic neural progenitor cells. Neurosci Lett 2004; 362: 117-121

165 Ahmad F, Khan MM, Rastogi AK, Kidwai JR. Insulin and glucagon releasing activity of coleonol (forskolin) and its effect on blood glucose level in normal and alloxan diabetic rats. Acta Diabetol Lat 1991; 28: 71-77

166 Yamamoto S, Nakadate T, Uzumaki H, Kato R. Lipoxygenase inhibitors and cyclic AMP-mediated insulin secretion caused by forskolin, theophylline and dibutyryl cyclic AMP. J Pharmacol Exp Ther 1985; 233: $176-180$

167 Leclercq-Meyer V, Malaisse WJ. Modulation of gliquidone action by forskolin in the pancreas of normal and GK rats. Am J Physiol 1997; 273: E52-E58

168 Mulhall JP, Daller M, Traish AM, Gupta S, Park K, Salimpour P, Payton TR, Krane RJ, Goldstein I. Intracavernosal forskolin: role in management of vasculogenic impotence resistant to standard 3-agent pharmacotherapy. J Urol 1997; 158: 1752-1759

169 Liu JH, Li Y, Cao ZG, Ye ZQ. Influences of dibutyryl cyclic adenosine monophosphate and forskolin on human sperm motility in vitro. Asian J Androl 2003; 5: 113-115

$170 \mathrm{Li} \mathrm{Y}$, Liu J, Ye H, Ye Z. Influence of forskolin on human sperm motility. Zhongguo Nankexue Zazhi 2004; 18: 23-25

171 van Sande J, Cochaux P, Mockel J, Dumont JE. Stimulation by forskolin of the thyroid adenylate cyclase, cyclic AMP accumulation and iodine metabolism. Mol Cell Endocrinol 1983; 29: 109-119

172 Laurenza A, Sutkowski EM, Seamon KB. Forskolin: a specific stimulator of adenylyl cyclase or a diterpene with multiple sites of action? Trends Pharmacol Sci 1989; 10: 442-447

173 Kashiwagi A, Huecksteadt TP, Foley JE. The regulation of glucose transport by cAMP stimulators via three different mechanisms in rat and human adipocytes. J Biol Chem 1983; 258: 13685-13692

174 Joost HG, Steinfelder HJ. Forskolin inhibits insulin-stimulated glucose transport in rat adipose cells by a direct interaction with the glucose transporter. Mol Pharmacol 1987; 31: 279-283

175 Sergeant S, Kim HD. Inhibition of 3-O-methylglucose transport in human erythrocytes by forskolin. J Biol Chem 1985; 260: 14677-14682

$176 \mathrm{Kim}$ HD, Sergeant S, Shukla SD. Glucose transport in human platelets and its inhibition by forskolin. J Pharmacol Exp Ther 1986; 236: 585589

177 Martin GE, Seamon KB, Brown FM, Shanahan MF, Roberts PE, Henderson PJ. Forskolin specifically inhibits the bacterial galactose $-\mathrm{H}^{+}$transport protein, GalP. J Biol Chem 1994; 269: 24870-24877
178 Hoshi T, Garber SS, Aldrich RW. Effect of forskolin on voltage-gated $\mathrm{K}^{+}$ channels is independent of adenylate cyclase activation. Science 1988; 240: 1652-1655

179 Matthias K, Seifert G, Reinhardt S, Steinhäuser C. Modulation of voltage-gated $\mathrm{K}(+)$ channels Kv11 and Kv14 by forskolin. Neuropharmacology 2002; 43: 444-449

180 Ono K, Fozzard HA, Hanck DA. A direct effect of forskolin on sodium channel bursting. Pflugers Arch 1995; 429: 561-569

181 Asai T, Pelzer S, McDonald TF. Cyclic AMP-independent inhibition of cardiac calcium current by forskolin. Mol Pharmacol 1996; 50: 1262-1272

182 Park TJ, Kim KT. Cyclic AMP-independent inhibition of voltage-sensitive calcium channels by forskolin in PC12 cells. J Neurochem 1996; 66: 83-88

183 Gandía L, Vitale ML, Villarroya M, Ramirez-Lavergne C, García AG, Trifaró JM. Differential effects of forskolin and 1,9-dideoxyforskolin on nicotinic receptor-and $\mathrm{K}^{+}$-induced responses in chromaffin cells. Eur J Pharmacol 1997; 329: 189-199

184 Shi LJ, Liu LA, Wang CA. Effect of forskolin on acetylcholine-induced current in rat pheochromocytoma cells. Acta Pharmacol Sin 2000; 21: 281-285

185 Fan P. Antagonism by forskolin of the 5-HT3 receptor-mediated current in nodose ganglion neurons is independent of cyclic AMP. Brain Res 1994; 650: 16-19

186 Oz M, Zhang L, Spivak CE. Direct noncompetitive inhibition of 5-HT3 receptor-mediated responses by forskolin and steroids. Arch Biochem Biophys 2002; 404: 293-301

187 Wadler S, Wiernik $P H$. Partial reversal of doxorubicin resistance by forskolin and 1,9-dideoxyforskolin in murine sarcoma S180 variants. Cancer Res 1988; 48: 539-543

188 Morris DI, Speicher LA, Ruoho AE, Tew KD, Seamon KB. Interaction of forskolin with the P-glycoprotein multidrug transporter. Biochemistry $1991 ; 30: 8371-8379$

189 Uboldi $A D$, Savage $N$. The adenylate cyclase activator forskolin partially protects L929 cells against tumour necrosis factor-alpha-mediated cytotoxicity via a cAMPindependent mechanism. Cytokine 2002; 19: 250-258

190 Sidhu JS, Omiecinski CJ. Forskolin-mediated induction of CYP3A1 mRNA expression in primary rat hepatocytes is independent of elevated intracellular cyclic AMP. J Pharmacol Exp Ther 1996; 276: 238-245

191 Dowless MS, Barbee JL, Borchert KM, Bocchinfuso WP, Houck KA. Cyclic AMP-independent activation of CYP3A4 gene expression by forskolin. Eur J Pharmacol 2005; 512: 9-13

192 Li Ping, Yang XL. Forskolin modulation of desensitization at GABAA and glycine receptors is not mediated by cAMP-dependent protein kinase in isolated carp amacrine-like cells. Pflugers Arch 2001; 441: 739-745

193 Middleton P, Jaramillo F, Schuetze SM. Forskolin increases the rate of acetylcholine receptor desensitization at rat soleus endplates. Proc Natl Acad Sci USA 1986; 83: 4967-4971

194 Miles K, Anthony DT, Rubin LL, Greengard P, Huganir RL. Regulation of nicotinic acetylcholine receptor phosphorylation in rat myotubes by forskolin and cAMP. Proc Natl Acad Sci USA 1987; 84: 6591-6595

195 Wagoner PK, Pallotta BS. Modulation of acetylcholine receptor desensitization by forskolin is independent of cAMP. Science 1988; 240 : 1655-1657

196 Middleton P, Rubin LL, Schuetze SM. Desensitization of acetylcholine receptors in rat myotubes is enhanced by agents that elevate intracellular cAMP. J Neurosci 1988; 8: 3405-3412

197 Berger CE, Datta HK. Forskolin has a bimodal cAMP-independent effect on superoxide anion generation in isolated osteoclasts. Exp Physiol 2000; 85: 57-60

198 Kreiger NS, Stern PH. Effect of forskolin on bone in organ culture. Am J Physiol 1987; 252: E44-E48

199 Ding X, Staudinger JL. Induction of drug metabolism by forskolin: the role of the pregnane $X$ receptor and the protein kinase A signal transduction pathway. J Pharmacol Exp Ther 2005; 312: 849-856

200 Putnam WC, Swenson SM, Reif GA, Wallace DP, Helmkamp Jr GM, Grantham JJ. Identification of a forskolin-like molecule in human renal cysts. J Am Soc Nephrol 2007; 18: 934-943

201 Yang W, Li X, Chen Z, Nie L, Wang B, Shen Z. Adenylate cyclase stimulation and ocular hypertension inhibition by forskolin analogs. Yanke Yanjiu 2001; 19: 1-4 
202 Bhat SV, Bajwa BS, Dornauer H, de Souza NJ, Fehlhaber HW. Structures and stereochemistry of new labdane diterpenoids from Coleus forskohlii Briq. Tetrahedron Lett 1977; 19: 1669-1672

203 Tandon JS, Jauhari PK, Singh RS, Dhar MM. Structures of three new diterpenes, coleonol $\mathrm{B}$, coleonol $\mathrm{C}$ and deoxycoleonol isolated from $\mathrm{Co}$ leus forskohlii. Indian J Chem Sect B Org Chem Incl Med Chem 1978; 16B: 341-345

204 Shan Y, Xu L, Lu Y, Wang X, Zheng Q Kong L, Niwa M. Diterpenes from Coleus forskohlii (Willd.) Briq. (Labiatae). Chem Pharm Bull 2008; 56: 52-56

205 Joost HG, Habberfield AD, Simpson IA, Laurenza A, Seamon KB. Activation of adenylate cyclase and inhibition of glucose transport in rat adipocytes by forskolin analogues: structural determinants for distinct sites of action. Mol Pharmacol 1988; 33: 449-453

206 Zerr P, Becherer U, Rodeau JL, Feltz A. Forskolin's structural analog 1,9dideoxyforskolin has Ca2+ channel blocker-like action in rat cerebellar granule cells. Eur J Pharmacol 1996; 303: 101-108

207 Li Z, Wang J. A forskolin derivative, FSK88, induces apoptosis in human gastric cancer BGC823 cells through caspase activation involving regulation of Bcl-2 family gene expression, dissipation of mitochondrial membrane potential and cytochrome c release. Cell Biol Int 2006; 30: $940-946$

208 Tandon JS, Roy R, Balachandran S, Vishwakarma RA. Epi-deoxycoleonol, a new antihypertensive labdane diterpenoid from Coleus forskohlii. Bioorg Med Chem Lett 1992; 2: 249-254

209 Sashidhara KV, Rosaiah JN, Kumar A, Bid HK, Konwar R, Chattopadhyay $N$. Cell growth inhibitory action of an unusual labdane diterpene, 13epi-sclareol in breast and uterine cancers in vitro. Phytother Res 2007; 21: 1105-1108

210 Shan Y, Wang X, Zhou X, Kong L, Niwa M. Two minor diterpene glycosides and an eudesman sesquiterpene from Coleus forskohlii. Chem Pharm Bull 2007; 55: 376-381

211 Liu Y, Wu H, Wang XM, Liu J, Xing X. Use of coleon C extracted from Coleus as inhibitor for tumor growth and tumor cell proliferation. Chinese Patent CN 1899273 A; 2007

212 Majeed M, Kumar A, Nagabhushanam K, Prakash S. Process for preparing water soluble diterpenes and their applications. US Pat Appl Pub US 2005/0284812 A1; 2005

213 Hosono M, Takahira T, Fujita A, Fujihara R, Ishizuka O, Ohoi I, Tatee T, Nakamura K. Cardiovascular effects of NKH477, a novel potent water-soluble forskolin derivative. Eur J Pharmacol 1990; 183: 2110

214 Laurenza A, Khandelwal Y, de Souza NJ, Rupp RH, Metzger H, Seamon $K B$. Stimulation of adenylate cyclase by water-soluble analogues of forskolin. Mol Pharmacol 1987; 32: 133-139

215 Saettone MF, Burgalassi S, Giannaccini B. Preparation and evaluation in rabbits of topical solutions containing forskolin. J Ocul Pharmacol 1989; 5: 111-118

216 Khandelwal Y, Rajeshwari K, Rajagopalan R, Swamy L, Dohadwalla AN, de Souza NJ, Rupp RH. Cardiovascular effects of new water-soluble derivatives of forskolin. J Med Chem 1988; 31: 1872-1879

217 Tatee T, Narita A, Narita K, Izumi G, Takahira T, Sakurai M, Fujita A, Hosono $M$, Yamashita K, Enomoto K, Shiozawa A. Forskolin derivatives. I. Synthesis, and cardiovascular and adenylate cyclase-stimulating activities of water-soluble forskolins. Chem Pharm Bull (Tokyo) 1996; 44: 2274-2279

218 Himeta M, Sakashita Y, Fujita A, Hosono M, Nakamura K. Characterization of the vasodilating effects of NKH477, a novel forskolin derivative, in isolated rat aorta, canine arteries and rabbit femoral arteries and veins. Yakuri To Chiryo 1998; 26: 775-785

219 Hosono M. Cardiovascular effects of colforsin daropate hydrochloride, a novel drug for the treatment of acute heart failure. Nippon Yakurigaku Zasshi 1999; 114: 83-88

220 Hirota K, Yoshioka H, Kabara S, Koizumi Y, Abe H, Sato T, Matsuki A. Spasmolytic effects of colforsin daropate on serotonin-induced pulmonary hypertension and bronchoconstriction in dogs. Acta Anaesthesiol Scand 2002; 46: 297-302

221 Ogata J, Minami K, Segawa K, Uezono Y, Shiraishi M, Yamamoto C, Sata T, Sung-Teh K, Shigematsu A. A forskolin derivative, colforsin daropate hydrochloride, inhibits the decrease in cortical renal blood flow induced by noradrenaline or angiotensin II in anesthetized rats. Nephron Physiol 2004; 96: 59-64

222 Uchida M, Iida H, Iida M, Kumazawa M, Sumi K, Takenaka M, Dohi S. Both milrinone and colforsin daropate attenuate the sustained pial arteriolar constriction seen after unclamping of an abdominal aortic cross-clamp in rabbits. Anesth Analg 2005; 101: 9-16

223 Nakashima S, Morikawa M, Komatsu K, Matsuura A, Sato N, Abe T. Antiproliferative effects of NKH477, a forskolin derivative, on cytokine profile in rat lung allografts. J Heart Lung Transplant 2005; 24 : 462-469

224 Onda T, Hashimoto Y, Nagai M, Kuramochi H, Saito S, Yamazaki H, Toya Y, Sakai I, Homcy CJ, Nishikawa K, Ishikawa Y. Type-specific regulation of adenylyl cyclase. Selective pharmacological stimulation and inhibition of adenylyl cyclase isoforms. J Biol Chem 2001; 276: 4778547793

225 Toya Y, Schwencke C, Ishikawa Y. Forskolin derivatives with increased selectivity for cardiac adenylyl cyclase. J Mol Cell Cardiol 1998; 30: 97-108

226 Sawaki S, Furukawa Y, Inoue Y, Takayama S, Chiba S. Positive chronotropic and inotropic responses to novel cardiotonics, NKH477 and MCI-154 in isolated, perfused canine heart preparations. Asia Pac J Pharmacol 1993; 8: 133-140

227 Takeuchi M, Takaoka H, Hata K, Mori M, Yamakawa H, Yamaguchi K, Yokoyama M. NKH477: a new inotropic agent. Cardiovasc Drug Rev 1995; 13: 339-352

228 Ishizuka O, Hosono M, Nakamura K. Profile of cardiovascular effects of NKH477, a novel forskolin derivative, assessed in isolated, blood-perfused dog heart preparations: comparison with isoproterenol. J Cardiovasc Pharmacol 1992; 20: 261-267

229 Hosono M, Takahira T, Fujita A, Fujihara R, Ishizuka O, Tatee T, Nakamura K. Cardiovascular and adenylate cyclase stimulant properties of NKH477, a novel water-soluble forskolin derivative. J Cardiovasc Pharmacol 1992; 19: 625-634

230 Takahira T, Hosono M, Sakitama K. Cardiovascular effects of NKH477 in experimental canine heart failure. Junkan Seigyo 1995; 16: 196203

231 Sanbe A, Takeo S. Effects of NKH477, a water-soluble forskolin derivative, on cardiac function in rats with chronic heart failure after myocardial infarction. J Pharmacol Exp Ther 1995; 274: 120-126

232 Ishizuka O, Fujita A, Kanbe E, Noguchi M, Hosono M, Sakitama K. Effectiveness of NKH477, a novel forskolin derivative, in rat cardiac preparations with desensitized beta-adrenoceptors. Nippon Yakurigaku Zasshi 1996; 108: 23-30

233 Mori M, Takeuchi M, Takaoka H, Hata K, Hayashi Y, Yokoyama M. Effect of NKH477, a new water-soluble forskolin derivative, on arterial-ventricular coupling and mechanical energy transduction in patients with left ventricular systolic dysfunction: comparison with dobutamine. J Cardiovasc Pharmacol 1994; 24: 310-316

234 Hayashida N, Chihara S, Tayama E, Kashikie H, Takaseya T, Hiratsuka $R$, Kai E, Enomoto N, Kawara T, Aoyagi S. Effects of colforsin daropate hydrochloride in patients undergoing coronary artery bypass surgery. Kyobu Geka 2001; 54: 391-395

235 Iranami H, Okamoto K, Kimoto Y, Maeda H, Kakutani T, Hatano Y. Use of colforsin daropate following cardiac surgery in a neonate. Anesthesiology 2002; 97: 503-504

236 Ogata J, Nakano K, Sakamoto K, Minami K. Preoperative use of colforsin daropate hydrochloride in a patient with severe cardiac function scheduled for Y-graft replacement. Anesth Analg 2001; 93: 10791080

237 Hayashida N, Teshima H, Tayama E, Chihara S, Enomoto N, Kawara T, Aoyagi $S$. Influence of colforsin daropate hydrochloride on internal mammary artery grafts. Circ J 2002; 66: 372-376

238 Hibino N, Kawai A, Uchikawa S, Chikazawa G, Kurihara T, Kihara S, Uebe K, Aomi S, Nishida H, Endo M, Koyanagi $H$. Cardiovascular effects of colforsin daropate hydrochloride for acute heart failure after open heart surgery. Kyobu Geka 2001; 54: 1016-1019 